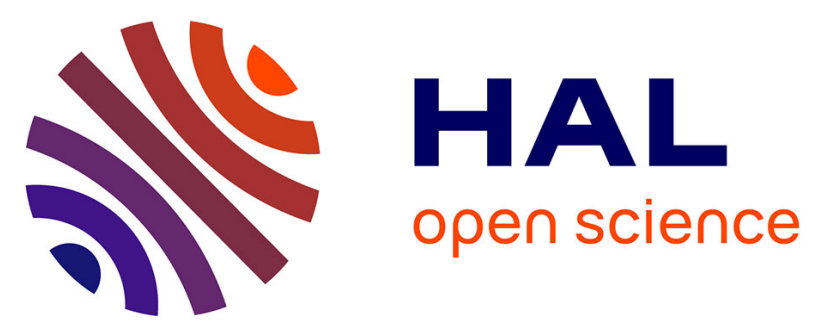

\title{
Groundwater isotopic data as potential proxy for Holocene paleohydroclimatic and paleoecological models in NE Brazil
}

\author{
Guillaume Bertrand, Ricardo Hirata, Augusto Auler, Francisco Cruz, Lise \\ Cary, Emmanuelle Petelet-Giraud, Eliot Chatton, Luc Aquilina, \\ Jean-Sébastien Moquet, Maria Gracia Bustamante, et al.
}

\section{To cite this version:}

Guillaume Bertrand, Ricardo Hirata, Augusto Auler, Francisco Cruz, Lise Cary, et al.. Groundwater isotopic data as potential proxy for Holocene paleohydroclimatic and paleoecological models in NE Brazil. Palaeogeography, Palaeoclimatology, Palaeoecology, 2017, 469, pp.92-103. 10.1016/j.palaeo.2017.01.004 . insu-01427249

\section{HAL Id: insu-01427249 \\ https://hal-insu.archives-ouvertes.fr/insu-01427249}

Submitted on 10 Jan 2017

HAL is a multi-disciplinary open access archive for the deposit and dissemination of scientific research documents, whether they are published or not. The documents may come from teaching and research institutions in France or abroad, or from public or private research centers.
L'archive ouverte pluridisciplinaire HAL, est destinée au dépôt et à la diffusion de documents scientifiques de niveau recherche, publiés ou non, émanant des établissements d'enseignement et de recherche français ou étrangers, des laboratoires publics ou privés. 


\section{Accepted Manuscript}

Groundwater isotopic data as potential proxy for Holocene paleohydroclimatic and paleoecological models in NE Brazil

Guillaume Bertrand, Ricardo Hirata, Augusto Auler, Francisco Cruz, Lise Cary, Emmanuelle Petelet-Giraud, Eliot Chatton, Luc Aquilina, Jean-Sébastien Moquet, Maria Gracia Bustamante, Christian Millo, Veridiana Martins, Suzanna Montenegro, Hélène

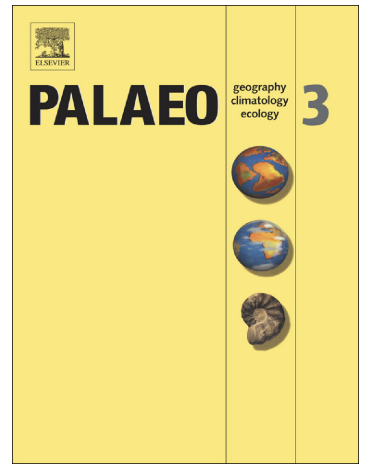
Celle-Jeanton

PII: $\quad$ S0031-0182(17)30003-2

DOI: $\quad$ doi: $10.1016 /$ j.palaeo.2017.01.004

Reference: $\quad$ PALAEO 8136

To appear in: $\quad$ Palaeogeography, Palaeoclimatology, Palaeoecology

Received date: $\quad 1$ March 2016

Revised date: $\quad 20$ December 2016

Accepted date: 1 January 2017

Please cite this article as: Guillaume Bertrand, Ricardo Hirata, Augusto Auler, Francisco Cruz, Lise Cary, Emmanuelle Petelet-Giraud, Eliot Chatton, Luc Aquilina, Jean-Sébastien Moquet, Maria Gracia Bustamante, Christian Millo, Veridiana Martins, Suzanna Montenegro, Hélène Celle-Jeanton, Groundwater isotopic data as potential proxy for Holocene paleohydroclimatic and paleoecological models in NE Brazil. The address for the corresponding author was captured as affiliation for all authors. Please check if appropriate. Palaeo(2017), doi: 10.1016/j.palaeo.2017.01.004

This is a PDF file of an unedited manuscript that has been accepted for publication. As a service to our customers we are providing this early version of the manuscript. The manuscript will undergo copyediting, typesetting, and review of the resulting proof before it is published in its final form. Please note that during the production process errors may be discovered which could affect the content, and all legal disclaimers that apply to the journal pertain. 


\section{Groundwater isotopic data as potential proxy for Holocene}

\section{paleohydroclimatic and paleoecological models in NE Brazil}

${ }^{1}$ Guillaume BERTRAND, ${ }^{2}$ Ricardo HIRATA, ${ }^{3}$ Augusto AULER, ${ }^{2}$ Francisco CRUZ, ${ }^{4}$ Lise CARY, ${ }^{4}$ Emmanuelle PETELET-GIRAUD, ${ }^{5}$ Eliot CHATTON, ${ }^{5}$ Luc AQUILINA, ${ }^{2}$ Jean-Sébastien MOQUET, ${ }^{2}$ Maria Gracia BUSTAMANTE, ${ }^{6}$ Christian MILLO, ${ }^{2}$ Veridiana MARTINS, ${ }^{1}$ Suzanna MONTENEGRO, ${ }^{7}$ Hélène CELLE-JEANTON

${ }^{1}$ Civil Engineering Department, Universidade Federal do Pernambuco, Avenida Professor Moraes Rego, n⿳亠丷厂 1235, bairro Cidade Universitária, Recife, Brazil, email: guillaume.bertrand@email.com, suzanam@ufpe.br

${ }^{2}$ Instituto de Geociências, Universidade de São Paulo, Rua do lago 562, 05508-080 Sao Paulo, Brazil, email: rhirata@usp.br, veridian@usp.br, js.moquet@gmail.com, bustamanterosell@gmail.com,cruz@usp.br ${ }^{3}$ Carste Consultores Associados, adrress: Rua Aquiles Lobo, 297 - Floresta - Belo Horizonte - MG - CEP. 30150-160, Brazil, email: aauler@gmail.com

${ }^{4}$ Bureau de Recherches Géologiques et Minières (BRGM), 3 avenue Claude-Guillemin BP 36009, 45060 Orléans Cedex 2 , France, email, 1.cary@brgm.fr, e.petelet@brgm.fr

${ }^{5}$ Géosciences Rennes, Université Rennes 1-CNRS, UMR 6118, Campus de Beaulieu 35042 Rennes Cedex, France, email: eliot.chatton@etudiant.univ-rennes1.fr, luc.aquilina@univ-rennes1.fr,

${ }^{6}$ Instituto Oceanográfico, Universidade de São Paulo (IO-USP), Praça do Oceanográfico, 191, 05508-900 São Paulo (SP), Brasil, email: millo@usp.br

${ }^{7}$ Chrono-Environnement, Université de Franche-Comté, CNRS UMR 6249, 16 Route de Gray, 25030 Besançon, France, email: helene.jeanton@univ-fcomte.fr

Abstract: Holocene paleoclimatic patterns in NE Brazil are recognized to present singular characteristics when compared with the remaining tropical South-America. In particular, isotopic variations in speleothem calcite highlight that in contrast to the rest of tropical SA, NE Brazil experienced humid conditions during lower summer insolation, i.e. throughout the Early-Mid Holocene, and aridity when, as nowadays, summer insolation was high. In parallel, paleobotanical and palynological investigations suggest that these wetter conditions, also associated with 
colder climate, could have promoted the setting of ecological corridors between the current Amazonian (continental) and Atlantic (littoral) forests. In this context, this work aims at showing how groundwater isotopic data could be used as a complementary proxy to further explain these Holocene paleohydroclimatic and paleoecologic processes. By comparing $\delta^{18} \mathrm{O}, \delta^{2} \mathrm{H}$ and d-excess of modern waters with Early-Mid Holocene groundwater in Recife (Pernambuco state, NE Brazil), differences in recharge patterns and moisture origin can be constrained. We find that Early-Mid Holocene waters present higher d-excess than the modern groundwater. Given that the Early-mid Holocene colder and wetter conditions (higher relative humidity) should lead to a reverse trend, i.e. lower d-excess, we hypothesize that the groundwater moisture sources was heavily recycled. Such a hypothesis would be consistent with the presence of a rainforest-type ecosystem, similar to the present Amazonian forest, in the currently arid NE Brazil. These observations highlight the potential added value of the groundwater isotopes proxy to discuss the interrelationships of paleohydrological and paleoecological patterns during the Early-Mid Holocene. These new proxies might allow the spatio-temporal extent of the above-mentioned ecological corridors to be discussed.

Keywords: Groundwater, $\delta^{18} \mathrm{O}$, d-excess, Rain forest, Holocene, Brazil

\section{Introduction}

Over the last two decades, the Holocene climate reconstructions for South-America Monsoon System (SASM) historically poor, have been subject to increasing investigation (Vimieux et al., 2009; Vuille et al., 2012; Prado et al., 2013a; Baker and Fritz, 2015). These reconstructions are based on combination of large-scale numerical models (e.g., IPSL-CM5A-LR, Kageyama et al., [2012] and references therein; MIROC-ESM, Watanabe et al. [2011]; CNRM-CM5, Voldoire et al. [2013], FGOALS-s2, Bao et al. [2013]; BCC-CSMI.I, Xin et al. [2013]) calibrated and controlled by various local proxy data.

These proxies include dated pollens records (e.g., Oliveira et al., 1999; Auler et al., 2004), lake sediment geochemical analyses (e.g., Viana et al., 2014), terrigenous pulses in ocean cores (e.g., Arz et al., 1999), travertine

deposits (e.g., Wang et al., 2004), tree rings (e.g., Ferrero et al., 2015), ice core $\delta^{18} \mathrm{O}$ variability investigations (mainly in the Andes; e.g., Thompson et al., 2013) and speleothem $\delta^{18} \mathrm{O}$ analyses (e.g., Cruz et al.,2005; 2009; Novello et al., 2012; 2016; Cheng et al.,2013). However, despite the current increasing interest in the South America 
(SA) paleoclimatic reconstruction, available proxies are still considered to be sparse for the area if they are compared to records from Northern Hemisphere (Vuille et al., 2012; Prado et al., 2013a;b).

Moreover, at the continent scale, the repartition of the proxies is heterogeneous. Multi-proxy reconstruction syntheses (e.g., Villalba et al., 2009; Prado et al., 2013a;b), have highlighted that the Brazilian North-East (referred to "Nordeste" hereafter) is still very poorly documented. This scarcity of paleodata for Nordeste is probably due to the current geologic and climatic contexts of the area. From a climatic point of view, Nordeste is nowadays mainly an arid region featuring caatinga vegetation and potential Holocene lacustrine/riverine sediment/pollen data accumulation and conservation are not in optimal conditions. In this area, only few data over the 3 last millenia from lacustrine sediments were investigated through geochemical proxies next to the seashore (Siffedine et al., 2011; Zocatelli et al., 2012). In parallel, investigation of speleothem isotopic records necessarily implies to find carbonated contexts with access to developed and unflooded karstic network, such geological conditions being not frequently found in Nordeste.

The few available data for the Nordeste for the whole or portions of the Holocene are nevertheless considered of good quality. Although calibration (against modern hydrometeorological data) and corrections (of long-term isotopic effects on moisture sources) are still discussed (Baker and Fritz, 2015; Moquet et al., 2016), these proxies are relevant, in term of time resolution, for detailed multidecadal and millenial variations of the SASM over the Nordeste (Cruz et al., 2009; Novello et al., 2012; Cheng et al., 2013), and contributed to describe the large scale drivers of SASM changes during the Holocene and the complexity of their interactions.

These indicators have allowed for rainfall intensity patterns to be delineated and forcing typologies to be produced which explain the "mosaic response" of the SA throughout the Holocene (Sylvestre, 2009). The major driver of the SAMS circulation is the land-sea temperature gradient (Vera et al., 2006; Marengo et al., 2012; Cruz et al., 2009; Prado et al., 2013a;b). During the Early-Mid Holocene, lower austral insolation in the Southern Hemisphere induced a less effective land-sea contrast than nowadays, combined with a lower moisture ascendant motion and rain cloud formation leading to a drier climate in the SAMS area. In addition, the latent heat released by the cloud formation was lower, and as this controls the high level circulation through the Bolivian High-Northeast Trough linkage, the subsidence over the Nordeste was lower than nowadays. This allowed for incursions in the area of both the Inter Tropical Convergence Zone (ITCZ) from the North and of the South Atlantic Convergence Zone 
(SACZ) from the South (Silvia-Dias et al., 2009), producing more precipitation in this zone while the rest of the SAMS zone was drier (Valdes, 2000; Cruz et al., 2009; Silva Dias et al., 2009; Cheng et al., 2013). Numerical simulations with general circulation models that incorporate basic atmospheric water isotope physics $\left({ }^{18} \mathrm{O}\right.$ and/or $\left.{ }^{2} \mathrm{H}\right)$ support this pattern by simulating the amount effect, as well as the link to insolation-driven monsoon activity (Cruz et al., 2009).

In parallel, a temperature cooling of the region during Early-Mid Holocene has been documented, although at a coarser time resolution, through pollen, oceanographic and noble gas data (e.g., Behling et al., 2000; Bush et al., 2007; Ledru et al., 1996; 2009; Stute et al., 1995; Wang et al., 2004; Santos et al., 2014). Despite of remaining uncertainties, it is now broadly accepted that this cooling ranged between 4 and $8^{\circ} \mathrm{C}$ over SA in comparison to the Late Holocene, and around $5^{\circ}$ in Nordeste (Farrera et al., 1999; Stute et al., 1995; Chatton et al., 2016).

Finally, palynological and paleobotanical records argued for the existence of ecological corridors between the Amazonian Forest and the coastal Atlantic Forest of NE Brazil, an area nowadays featuring an arid caatinga phytogeographical domain (Oliveira et al., 1999; Auler et al., 2004; Cheng et al., 2013 and references therein). These resulting vegetation changes were partially modeled in climatic simulations by Silva Dias et al. (2009).

Nevertheless, two main gaps have been identified in the understanding of the Holocene climatic trends of Nordeste, which still preclude a comprehensive scheme of the SA response to insolation driven patterns. First, more proxy data are still necessary for evaluating the magnitude and impacts of the SAMS variability over the Nordeste precipitation patterns. Second, the possible vegetation changes and their dynamics during this period still need to be clarified, as vegetation-based modeling requires proxies of vegetation impacts on hydroclimatological processes (Silva Dias et al., 2009). In addition, although the ecological corridor theory is supported by paleobotanical clues, the hypothesis of a more widespread hydro-ecological connection between Amazonian basin and NE Brazil (Oliveira et al., 1999; Auler et al., 2004), which would have strong consequences on rainfall nature and distribution, has yet to be strengthened.

To address this, our work aims to present insights about the potential for water isotope proxies (deuterium, oxygen-18 and deuterium excess referred to d-excess in the following) from ${ }^{14} \mathrm{C}$ dated groundwater sampled in Nordeste in the perspective of evaluating the vegetation impacts on hydroclimatological processes and reciprocally, the hydrological changes to Holocene ecological variability. Our findings are based on dated paleogroundwater 
isotopic data primarily acquired in the purpose of hydrogeological investigations (2012-2015 Coqueiral project ; Cary et al., 2015; Chatton et al., 2015; 2016; Bertrand et al., 2016) but whose the patterns were significantly different from the expected trends, in comparison to Holocene paleogroundwater isotopic records found elsewhere in subtropical conditions. On the basis of these observations, we present new hypotheses regarding Holocene potential paleoecological and paleohydrological trends of the Nordeste.

\section{Site description}

The studied system, known as the Recife sedimentary aquifer system (Figure 1), is located in the Pernambuco state in Brazil $\left(8^{\circ} 04^{\prime} 03^{\prime \prime} \mathrm{S}, 34^{\circ} 55^{\prime} 00^{\prime \prime} \mathrm{W}, \mathrm{z}_{\text {mean }}=5\right.$ masl). The studied area is urbanized and contains numerous surficial channels. The upstream area corresponding to the regional substratum, is, as the whole continental Nordeste, an arid to semi-arid area similar to Caatinga or Cerrado systems (Powell and Still, 2009; Cheng et al., 2013), comprised of a low arboreal deciduous scrubland where the vegetation is dormant and leafless for much of the year (Auler et al., 2004). On the seashore, Atlantic forest and mangrove ecosystems stands are found. The aquifer system lies over the Pernambuco and Paraíba basins, separated by the regional transverse structure of the Pernambuco Lineament (Figure 1). It is composed by the deep systems Cabo and Beberibe of Cretaceous age, reaching a maximum depth of $250 \mathrm{~m}$ in the studied area (Cary et al., 2015; Bertrand et al., 2016). These two systems are overlaid by Tertiary and Quaternary sediments forming the superficial aquifers Boa Viagem and Barreiras. Details on the geological and environmental settings may be found in Cary et al. (2015).

The hydrogeological pattern consists in flowlines following the general hydrographic gradient from the western part of the area to the coastline on the east (Cary et al., 2015; Chatton et al.,2016, Figure 2). The recharge of the modern groundwater mainly occur both vertically from the surface and horizontally from hydraulic connection with the regional substratum. Deep aquifer are mainly fed through to the recharge over the regional substratum, although punctual hydraulic connections occur with the shallow systems next to the seashore due to intensive exploitation pumping. For the deep groundwater systems (Cabo and Beberibe), investigations on recharge temperatures (reported in Table 1) through noble gas $(\mathrm{Ar} / \mathrm{Ne})$ analyses suggest a mean recharge temperature around 5 degrees below the current mean air temperature (Chatton et al., 2016). According to Stute et al (1995), such 
recharge temperatures are in agreement with a recharge during the Last Glacial Maximum or Early Holocene. These authors found similar recharge temperature for 7-20 Kyrs old groundwater in the Maranhão Basin, Piaui state $\left(7^{\circ} \mathrm{S}\right.$, $41,5^{\circ} \mathrm{W}$ ). In contrast, the shallow groundwater system of Recife (Boa Viagem and Barreiras) showed an inferred recharge temperature similar to the current mean annual air temperature of $25^{\circ} \mathrm{C}$ in the area (WMO, 2013; Chatton et al., 2016).

\section{Methodology}

Significant differences in recharge temperature suggest distinct recharge periods between the deep and the superficial systems (Chatton et al., 2016), and motivated further dating and analyses of stable isotopes described in the rest of this paper. We performed sampling and data acquisition in March 2013 and March 2014, at the end of the rainy period (September-March), in production wells of the 4 main aquifers (deep aquifers Cabo and Beberibe; shallow aquifers Barreiras and Boa Viagem). Surface water was sampled upstream and downstream in the Beberibe River, close to the estuary, in the Capibaribe river, as in the COMPESA (Pernambuco State Water and Sanitation Agency) drinking water treatment plants (Table 1).

Deuterium and oxygen-18 of water were measured on raw water using a Picarro Laser spectrometer L2130i at USP and reported on the usual $\delta$-scale in \%o relative to V-SMOW standard, according to Eq. 1 :

$$
\delta_{\text {sample }}(\%)=\left(\mathrm{R}_{\text {sample }} / \mathrm{R}_{\text {standard }}\right) * 1000, \quad \text { Eq. } 1 .
$$

where $\mathrm{R}$ is the ${ }^{2} \mathrm{H} /{ }^{1} \mathrm{H}$ and ${ }^{18} \mathrm{O} /{ }^{16} \mathrm{O}$ isotope ratios. Our analytical uncertainty is $\pm 0.1 \%$ for $\delta^{18} \mathrm{O}$ and $\pm 0.9 \%$ for $\delta^{2} \mathrm{H}$. We post-processed all the measurements according to IAEA and USGS (2013).

For ${ }^{14} \mathrm{C}$ dating, we collected a $1 \mathrm{~L}$ aliquot in high-density plastic bottles and we analyzed the sample by accelerator mass spectrometry at the BRGM (French Geological Service, Orléans, France). We measured $\delta^{13} \mathrm{C}_{\mathrm{TDIC}}$ according to the procedure of Kroopnick et al. (1970). We obtained a carbonate precipitation by adding $\mathrm{NaOH}$ $\left(\mathrm{pH}[12)\right.$ and $\mathrm{BaCl}_{2}$ in water samples. A precipitate of $\mathrm{BaCO}_{3}$ was then obtained and dried. We added phosphoric acid to the dry $\mathrm{BaCO}_{3}$ sample inside a vacuum line, and we purified and trapped the evolved $\mathrm{CO}_{2}$ with liquid nitrogen in a glass tube. Then, we measured the isotopic composition of this gaseous $\mathrm{CO}_{2}$ with a dual inlet mass spectrometer. 
The ${ }^{14} \mathrm{C}$ activity was measured relative to the modern carbon reference and expressed in $\%$ of modern carbon (pMC). The calibration of ${ }^{14} \mathrm{C}$ age of groundwater is usually subject to various assumptions depending on the studied groundwater system geological characteristics (see e.g., Fontes and Garnier, 1979; Cheng, 1992). These assumptions may imply possible influence of dead carbon through to carbonated matrix dissolution, carbon isotope exchanges between the various $\mathrm{C}$ phases along the groundwater flowpath in open and/or closed system (both estimated measuring ${ }^{13} \mathrm{C}$ and dissolved inorganic carbon speciation), initial activity soil ${ }^{14} \mathrm{CO}_{2}$ which entered the aquifer at the time of recharge. In the context of this study, we hypothesized a very limited influence from carbonated matrix i.e. no ${ }^{14} \mathrm{C}$ dilution, as the deep aquifers mainly consist in siliciclastic sediments (Cary et al., 2015; Bertrand et al., 2016), and that groundwater flows mostly in closed conditions, similarly to the empirical Vogel's approach (1970). In such a conceptual framework, the ${ }^{13} \mathrm{C}$ variability of dissolved inorganic carbon is only attributed to changes in soil ${ }^{13} \mathrm{CO}_{2}$, depending on the plant type over the recharge area and $\mathrm{C}$ speciation (see e.g., Bertrand et al., 2013 and references therein). For this study, considering the suspected changes in vegetation type during the Holocene (Powell and Still, 2009; Oliveira et al., 1999), the equilibrium ${ }^{13} \mathrm{CO}_{2}$ variability may be resulting from changes from $\mathrm{C} 4$ plants $\left({ }^{13} \mathrm{C}_{\mathrm{CO} 2}=-10\right.$ to $-15 \%$ vs $\mathrm{PDB}$ ) to $\mathrm{C} 3$ plants (around $-25 \%$ vs $\mathrm{PDB}$ ) respiration, and therefore has not been used for ${ }^{14} \mathrm{C}$ age calibration. This does not impact age calculation given that matrix carbonate influence is neglected considering the geological context of the aquifers.

In contrast, we took into account the specific correction for South Hemisphere atmosphere ${ }^{14} \mathrm{C}$ production SHcal13 (Hogg et al., 2013) through the Calib program (Stuiver et al., 2005). The uncertainties $\sigma$ calculated according to Scott et al., (2007) and the SHcal13 curve allowed for an evaluation of age ranges with a $2 \sigma$ uncertainty (95\% confidence; Table 2$)$.

\section{Results and discussion}

\subsection{Isotopic patterns of groundwater in the Recife aquifer system: differences between modern and paleo recharges}

The ${ }^{14} \mathrm{C}$ dating performed for the deep groundwater samples in Recife allowed for a recharge period to be estimated ranging from -4.6 kyrs to -20 kyrs BP, with the greatest proportion corresponding to -6 to -13 Kyrs B.P, 
i.e. largely during the Early-Mid Holocene (Table 2). Conversely, the shallow groundwater systems (Boa Viagem and Barreiras) contain CFC's and SF6 concentrations suggesting a modern components of their recharge (Supplementary material Table S1). At a first insight, the large range of ages in paleogroundwater highlight their potentiality for Holocene climate reconstruction, although the coarse time resolution still preclude a detailed evaluation of paleoclimatic processes, and that only low frequency processes should be addressed through these data.

Concerning the stable isotopes of water, shallow groundwater plot along a "modern groundwater line" (MGL; $\delta^{2} \mathrm{H}=4,5 \delta^{18} \mathrm{O}+5,7$ ) indicating recharge by modern precipitation, represented by the Local Meteoric Water Line built from 1 year sampling (LMWL; $\delta^{2} \mathrm{H}=7,4 \delta^{18} \mathrm{O}+11,1$; Figure 3A; Table 3) and the Ceará Mirim (located $300 \mathrm{~km}$ northern Recife) MWL built from 3 years monitoring (between 1973 and 1975 through the IAEA/WMOGNIP network, 2016), followed by secondary evaporation processes. This indicates infiltration of the numerous channels featuring the area (Cary et al., 2015). In contrast, the deep groundwater tends to slightly plot above the LMWL and presents richer signatures than modern groundwater, with a trend suggestive of recharge similar to the current Manaus meteoric water line (LMWL; $\delta^{2} \mathrm{H}=8,1 \delta^{18} \mathrm{O}+13,5$; Gat and Matsui, 1991) within the Amazonian basin $\left(03^{\circ} 06^{\prime} \mathrm{S} 60^{\circ} 01^{\prime} \mathrm{W}\right)$ (Figure $\left.3 \mathrm{~A}\right)$, and argues, in addition, for the absence of significant evaporation of the water entering the deep aquifers.

These differences can be further examined through the analyses of the deuterium excess ("d-excess") (Dansgaard, 1964; Eq. 2). This parameter is primarily, in atmospheric waters, inversely proportional to the relative humidity $(\mathrm{RH})$ in the evaporation area further providing the moisture leading to cloud formation and rainfall (Dansgaard, 1964; Clark and Fritz, 1997). d-excess can then be altered by evaporation (Rozanski, 1985).

$\mathrm{d}=\delta^{2} \mathrm{H}-8 \delta^{18} \mathrm{O} \quad$ Eq. 2

In precipitation, the d-excess mean $_{\text {at }}$ Recife (March 2013-Feb 2014) is $11.8 \%$. This value is a bit higher than the range from 10.3 to $11.2 \%$ observed by Gat and Matsui (1991), through to IAEA-GNIP network, for rainy season on the coastal cities of Nordeste around Recife (Fortaleza, Natal, Salvador). This latter is however probably more representative of infiltrating waters over the last decades in the area. Similarly the average of d-excess in precipitation for 3 entire hydrological years (1973-1975) at Ceara Mirim is lower with a mean value of 9.8\%. 
In aquifers, $d$-excess for paleogroundwater is higher ( $d$-excess mean $=12,4 \%$ ) than for modern groundwater $\left(\mathrm{d}\right.$-excess $\left.\mathrm{mean}_{\text {man }}=9 \%\right)$ and recharge (Figure 3B). This is a pattern that contrasts with the usual paleowaters recharged in colder and wetter conditions as reported in many other areas throughout the world, especially in subtropical environments (Clark and Fritz, 1997; Rozanski, 1985; Rozanski et al., 1997). For instance, in North-Africa, Holocene paleogroundwaters present a mean d-excess of about 5\%o lower than modern precipitations, related to higher RH over moisture source (colder conditions) during that period (Rozanski, 1985). This suggests that the dexcess-shift observed between shallow (modern) and deep (Early-Mid Holocene) groundwater in Recife cannot be attributed to the only increase of rainfall amount and insolation/temperature decreases (Stute et al.,1995; Cruz et al., 2009; Chatton et al., 2016) which should favor depleted $\delta^{18} \mathrm{O}, \delta^{2} \mathrm{H}$ (amount and temperature effects, Clar and Fritz, 1997), higher regional RH and therefore lower d-excess, and suggests that additional processes altering moisture sources occurred between the Early-Mid Holocene and the present day.

These preliminary observations highlight the interest of the groundwater isotopic signatures as a possible complementary tool for paleoclimate studies over the Nordeste region. In this context, a control of the sensitivity of these parameters in comparison to other available and well constrained proxy data is required. In addition the observed d-excess need to be understood in the paleoclimatic context of the area.

\subsection{Comparison of regional speleothem $\delta^{18} \mathrm{O}$ and ${ }^{14} \mathrm{C}$-dated groundwater isotopic fingerprints : rainfall amount and moisture source pattern changes during Holocene}

In NE Brazil, it was demonstrated that the main factor affecting the temporal isotopic signatures variability of precipitation is the amount effect (Cruz et al., 2009; Baker and Fritz, 2015, and references therein). On this basis, speleothem $\delta^{18} \mathrm{O}_{\text {carbonate }}$ which follows the average $\delta^{18} \mathrm{O}$ variability of drip water entering the karstic systems (Rainha, Furna Nova and Abissal caves, located at $05^{\circ} 36^{\prime} \mathrm{S}, 37^{\circ} 44^{\prime} \mathrm{W}$ at 100 masl and at $100 \mathrm{~km}$ distance from the Atlantic coast in the Rio Grande do Norte; Figure 3) was extensively used as a proxy of precipitation amount variation in the area (Cruz et al., 2009; Cheng et al., 2013). This proxy was shown, especially for the Early-Mid Holocene period, to capture shifts in the location of the ITCZ related to austral summer insolation (Figure 4A). 
By assuming isotopic equilibrium between the drip water supplying the speleothem and carbonate at the time of precipitation (using Eq. 3; Böhm et al., 2000; Affek et al., 2008 ; Kluge et al., 2013), we compared $\delta^{18} \mathrm{O}_{\mathrm{H} 2 \mathrm{O}}$ inferred from $\delta^{18} \mathrm{O}_{\text {carbonate }}$ and the isotopic signatures of our groundwater samples.

$\delta^{18} \mathrm{O}_{\text {carbonate }}-\delta^{18} \mathrm{O}_{\mathrm{H} 2 \mathrm{O}}=1000 \ln \alpha_{\text {carbonates- } \mathrm{H} 2 \mathrm{O}}=18.03\left(1000 \mathrm{~T}^{-1}\right)-32.17 \quad$ Eq. 3

Calculated $\delta^{18} \mathrm{O}_{\mathrm{H} 2 \mathrm{O}}$ range (from -7 to $-0,9 \%$ vs VSMOW) is significantly different (usually lower) from the measured $\delta^{18} \mathrm{O}_{\text {groundwater }}$ (varying from $-1,5$ to $-1,1 \%$ vs VSMOW) (Figure 4B). These differences may be the result of hydrogeological and/or physical and chemical processes. From a hydrogeological point of view, the more depleted signature of drip water fed by karstic system can be explained by a rapid infiltration of water within large fissures featuring karst in some places, limiting previous isotopic enrichment through to evaporation effect near the surface, which would conversely give increased $\delta^{18} \mathrm{O}$ values in deposited calcite (Fairchild et al., 2006; Baker and Bradley, 2010). Depending on the geometry of the system and the degree of connection between the surface and the percolation pathway feeding the speleothem, huge $\delta^{18} \mathrm{O}_{\mathrm{H} 2 \mathrm{O}}$ differences from a speleothem to another may occur, even in the same network. This leads to high variability of the equilibrated $\delta^{18} \mathrm{O}_{\text {carbonates }}$ between speleothem from neighboring or even identical caves (Ford and Williams, 2007, and references therein). Consistently, Serefiddin et al. (2004) pointed out a difference of $5 \%$ for $\delta^{18} \mathrm{O}_{\text {carbonates }}$ for speleothems spanning the same periods and from neighboring caves fed by two distinct karstic networks. In addition, beyond the likely different recharge conditions occurring in Recife (featured by crystalline and sedimentary lithologies) isotope ratios in groundwater we measured at our site may be buffered by hydrogeological processes. Groundwater circulation is constrained by potentiometric heads organized as equipotentials in aquifer, resulting in a nested organization of parallel flowlines between which mixing is limited (Toth, 1963) : local flow systems occur relatively close to the surface, i.e. from a higher elevation recharge area to a directly adjacent discharge area such as a stream or spring, whereas intermediate and regional flows reach to a greater depth in the aquifer. However, the recharge processes (e.g., mixing in the soil zone) buffer precipitation variability (including $\delta^{18} \mathrm{O}$ ), and limits time resolution. Therefore the resulting $\delta^{18} \mathrm{O}$ of the sampled groundwater could show a lower sensitivity than $\delta^{18} \mathrm{O}_{\text {carbonate }}$ to high frequency isotopic variability of precipitation. From a physical and chemical perspective, it is also possible that isotopic equilibrium and carbonate saturation within the drip water supplying the speleothem are only reached after the latest fractions of rain events, usually more depleted than the bulk rain water reaching the groundwater system. In spite of these differences whose specific reasons are out the scope of this paper, a co-variation of $\delta^{18} \mathrm{O}_{\text {carbonate }}$ and $\delta^{18} \mathrm{O}_{\text {groundwater }}$ is observable for the Early-Mid 
Holocene (Figure 4B). This suggests that dated groundwater could be a possible amount effect proxy in complement to speleothems, although it is buffered and of lower resolution.

In parallel and although the number of dated groundwater data is limited to 13 , d-excess appears to be related to the insolation (Figure 4C). The insolation decrease, while associated with increase in precipitation in the area, seems to be followed by a d-excess increase trend, after a time-lag. This trend strengthens the idea, as mentioned previously, that regional moisture origin has changed between the Early-Mid Holocene and today. This can reflect a temporal modification of the RH over a unique moisture source, spatial modifications of moisture origin and/or a higher recycling of local precipitations, providing a kinetically fractionated vapour (Salati et al., 1979; Rozanski, 1985; 1993; Gat and Matsui, 1991; Clark and Fritz, 1997). We discuss these possibilities below.

\subsection{Spatio-temporal changes in moisture sources: Paleoecological shifts over Nordeste during the Holocene}

The current spatial moisture pattern over northern tropical SA is mainly driven by the SAMS circulation which transports, during austral summer, tropical Atlantic moisture that is largely recycled over the Amazon basin westward toward the Andes. The warm and humid air masses are then deflected southward by the Andes through to the Andean low-level jet, transporting moisture towards southeastern SA (Cheng et al., 2013).

The westward Atlantic- Amazon basin moisture transport trend was firstly assessed by Salati et al. (1979) and analyzed by Gat and Matsui (1991) along a transect across northern Brazil, from Belem to Santarem and Manaus (Figure 3A), yielding an overview of isotopic variability in precipitation. These authors primarily highlighted a shift to more negative $\delta$ data values toward inland stands. This is related to the expected continental effect, describing the impoverishment trend in heavy isotopes in precipitation between littoral and continental stands resulting from rainout advancement (Clark and Fritz, 1997). However, the most prominent characteristic of rainfall precipitation signatures was the increase in d-excess from 7,5\%o near the coast in Belem to about $13 \%$ at Manaus, as in other inland cities such as Porto Velho, Cuiaba and Brasilia. This spatial pattern was attributed to evaporation from open water bodies and from the large rainforest canopy interception (Figure 5). While transpiration by plants does not lead to isotopic fractionation (Zimmerman et al., 1967), re-evaporation from open water bodies and 
interception leads to the production $\left(\mathrm{F}_{\text {evap }}\right)$ of a kinetically fractionated vapor $\left(\delta_{\text {evap }}\right)$. This re-evaporated flux mixes with the long-range moisture transport corresponding, after a progressive Rayleigh's distillation equilibrium fractionation of the Atlantic moisture $\left(\mathrm{F}_{\text {vap } 1} ; \delta_{\text {vap1 } 1}\right)$, to the remaining cloud water $\left(\mathrm{F}_{\text {vap2 }} ; \delta_{\text {vap2 }}\right)$ (Figure $\left.5 \mathrm{~A}\right)$. Such a mixing leads to an increase of the d-excess in the resulting moisture and precipitation $\left(\delta_{\text {vap3 } 3} \delta_{\mathrm{P} 2}\right)$ (Figure $\left.5 \mathrm{~B}\right)$. In the Amazonian basin, open water and canopy interception re-evaporation $\left(\mathrm{F}_{\text {evap }}\right)$ potentially accounts for $35 \%$ of the total evapotranspiration $\left(\mathrm{F}_{\text {evap }}+\mathrm{F}_{\text {transp }}\right)$ (Gat and Matsui, 1991). Various estimations of the portion of the total evapotranspiration then participating to the local precipitation $\left(\mathrm{F}_{\text {evap_rec }}+\mathrm{F}_{\text {transp_rec }}\right)$ were proposed (reviewed in Rocha et al. [2015] and Eltahir and Bras [1994]) and range from $16 \%$ in eastern border of the Amazon basin (Lettau et al., 1979) to $56 \%$ (Marques et al., 1956).

To account for this additional processes, an analytical steady-state evapotranspiration isotopic model was proposed and tested by Gat and Matsui (1991). to evaluate the sensitivity of d to the RH and runoff ratios vs rainout ratio. According to these tests, the $3 \%$ difference between coastal and inland d-excesses would be consistent with a recycling of half the precipitation, of which 20 to $40 \%$ would be from open water bodies in an environment featured by a mean RH of $75 \%$

In this context, the d-excess differences between deep paleogroundwaters and modern recharge and groundwater in Recife could be explained either by the past influence of a distant moisture source similar to the present central Amazon basin, or by a local change in ecosystem type. Indeed, a tropical rain forest like in the Amazon basin does not exist in Nordeste nowadays, this area being arid to semi-arid. Forest stands are limited, and exist only from the seashore to the coastal Atlantic forest. The only relatively large water bodies are located along the seashore and consist in estuary and mangroves, i.e. presenting similar isotopic features as seawater. Nevertheless, Silva-Dias et al. (2009) suggest, through modeling approaches that Early-Mid Holocene rainfall increase in Nordeste and related processes such as ITCZ southward shift and SACZ northward displacement, could be accompanied by a positive vegetation feedback, implying a potential role for paleoecological conditions at the continental scale (Figure 5C;D).

Consistently, the paleobotanical and palynological investigations in Nordeste for the Early-Mid-Holocene argued for the existence of transitional ecological corridors between the present Amazonian rain forest and the Coastal Atlantic Forest. This hypothesis was first suggested by floristic disjunctions revealed by studies of humid 
forests enclaves in high elevations within the semi-arid region of the caatinga phytogeographical domain (AndradeLima, 1966, 1982; Rizzini, 1967; Oliveira et al., 1999). These studies show that Tropical forest taxa are well represented throughout the Holocene in Nordeste such as in Icatu River Valley $\left(10^{\circ} 24^{\prime} \mathrm{S} 43^{\circ} 13^{\prime} \mathrm{W}, \mathrm{z}=400 \mathrm{~m}\right)$ which was dominated by gallery forest taxa from 10,060 to 6790 yrs B.P.

Hence, the reported d-excesses in Early-Mid Holocene paleogroundwaters in Recife (Figure 3B and 4C) strengthen the hypothesis of the existence of such a paleoecological shift in NE Brazil during the Early-Mid Holocene. The rainfall increase coupled with a mean temperature cooling alone does not explain the recycling signature of the Recife's paleogroundwater,. Our observation rather involves an alternative explanation: the Gat and Matsui scheme (1991) (Figure 5C) could have occurred closer to the Nordeste coast (Figure 5D). Such a hypothesis is strengthened by the time lag of temporal d-excess variation in paleogroundwater compared to insolation and precipitation changes (Figure 4C). This lag could result from the dynamics of ecological processes, i.e. the time required for the rain forest ecosystem settlement, necessary to trigger significant moisture recycling, a process that seems to be optimal after the maximum insolation phase. Our data suggest that such shift could have occurred, in Recife area earlier than e.g., Icatu River valley, as highest d-excess values are found at about 13100 yrs B.P in Recife. These findings need however to be further comfirmed by more detailed investigations.

In this context, it should be noted that although the concept of a more forested Nordeste and the existence of migration routes have been hypothesized for decades, the location of such routes and the timing of forest expansion phases remained unclear (Auler et al., 2004). Our hypothesis is in agreement with at least one of the hypothesized routes (Auler et al., 2004; Cheng et al., 2013; Oliveira et al., 1999), connecting hydro-ecologically the Recife area to the Amazon basin (Figure 5C). Nevertheless, the significant d-excess shift observed in the long-term for the deep groundwater system rather argues for more widespread ecological changes leading to the formation of an extended regional rain forest ecosystem (Figure 5D), as suggested by Auler et al., (2004). Such widespread shift provided the conditions to deeply recycle local moisture, portion of which then entered the aquifers.

\section{Concluding remarks on future challenges and use of isotopic proxy data in}

\section{Nordeste groundwater}


The use of d-excess is already largely implemented in dated ice cores to evaluate past moisture source relative humidity conditions (e.g., Steffensen et al., 2008) and/or location changes due to modification in atmospheric circulations (e.g. Masson-Delmotte et al., 2005) and is increasingly monitored in global precipitation and groundwater to validate Global Climate Model simulations (Pfhal and Sodemann, 2014). Our findings should encourage new validation exercises for isotope-enabled GCMs or Earth System Models of Intermediate Complexity (EMICs). Specifically, the modules related to soil-atmosphere interactions could be better constrained by integrating changes in recycling processes from continental surface water evaporation, which seem of great importance in intertropical zones like in Nordeste. Usually, incorporation of water isotopes in GCMs or EMICS (see the Stable Water Isotope Intercomparison Group projects, e.g., Kurita et al. [2011]; Risi et al. [2010]) implies to incorporate soil hydrology and atmospheric postcondensation exchanges in the model physics. Such efforts are currently made (e.g., Dee et al., 2015) and highlight the importance of the knowledge of the ecosystem type to better constrain proportion of evaporation versus transpiration recycling processes through d-excess (Jaseckco et al., 2013; Dee et al., 2015). This is yet challenging for present day modeling but can be constrained thanks to observational network (e.g., IAEA/WMO, 2016). For paleoclimatologic studies, such calibration is difficult as d-excess, requiring combined ${ }^{18} \mathrm{O}$ and ${ }^{2} \mathrm{H}$ data, is only sparsely available over glacial-interglacial time scales, and mainly in ice cores (Werner et al., 2016). As it is illustrated in this study, paleogroundwater data could provide a valuable help to integrate the dynamic behavior of ecosystem settlements through modifying land/soil modules over large time scales and calibrate these models in mid-latitude areas.

Nevertheless, it should be noted that isotope variability, as evaluated in groundwater, suffers limitations. Due to the integrative reservoir function of such large aquifers, and although nested organization of flow lines following equipotential downgradients (Toth, 1963) rather ensures temporal segregation from shallow to deeper aquifer layers, time resolution can be lower than for other proxies, e.g., speleothems, lake sediment cores (Rozanski, 1985; Corcho Alvarado et al., 2011; Jiráková et al., 2011; Jasecko et al., 2015). In addition, groundwater exploitation through to extensively screened wells (over several meters), such as in Recife may lead to mixing of water of various ages and alter the resolution of the recorded isotopic signatures.

Despite these limitations, however, the presented results illustrate the usefulness of our approach through further strategic sampling. This sampling should be performed on specifically designed low pumping rate wells to limit mixing processes potentially altering isotopic signals and time resolution. Another advantage is that d-excess 
data in groundwater can be simultaneously investigated with recharge temperature inferred from noble gas (e.g., Stute et al., 1995; Chatton et al., 2016) to complete rainfall amount information obtained from e.g., speleothems and obtain a more comprehensive overview of climatological parameters at the moment of the recharge. In addition, It should be noted as well that the potential timescale for paleoclimate reconstruction in the Recife area is much higher in the south of the city than in the zone investigated for the present study. The depth of the Pernambuco basin Piedade's Graben much less exploited for groundwater pumping, is deeper than $3000 \mathrm{~m}$ (Cary et al., 2015), and therefore has the potential to contain older paleowaters, especially next to the seashore according to the regional general flowpath (Figure 2). Consequently, both better adapted sampling and investigations at greater depths should provide a valuable support for our findings regarding paleoclimatological patterns in Nordeste and NE SouthAmerica, especially by tracing the recycling effects in regional moisture patterns. This should help to reciprocally diagnose a more detailed spatio-temporal typology of Holocene ecological changes, which appear, thanks to the reported new isotopic proxies, to be likely much more widespread than narrow ecological corridors between Amazonian basin and the Atlantic forest.

\section{$\underline{\text { Acknowledgements }}$}

This communication was possible thanks to a former study focusing on the Recife area hydrogeological functioning, part of the French-Brazilian COQUEIRAL project, financed by ANR CEP\&S (ANR-11-CEPL-012) / FACEPE (APQ-0077-3.07/11) / FAPESP (2011/50553-0). It is accredited by the French competitiveness cluster DREAM. Consortium: BRGM, CeRIES Lille 3 University, CAREN Rennes 1 University, GEOHYD, UFPE, USP, APAC, CPRM, INPE. The authors thank local authorities and owners for allowing access to wells and all colleagues and students involved in the sampling campaigns. G. Bertrand thanks O. Samperez, M. Bertrand, D. Bertrand for the material support during the elaboration of the manuscript. The authors greatly thank the two anonymous reviewers and the editor which did important remarks and provided very detailed comments for the improvement of the manuscript, and A. Merayan for the language checking. 


\section{References}

Affek H.P., Bar-Matthews M., Ayalon A., Matthews A., Eiler J.M., 2008. Glacial/interglacial temperature variations in Soreq cave speleothems as recorded by "clumped isotope" thermometry. Geochim. Cosmochim. Ac. 72, $5351-5360$.

Andrade-Lima D., 1966. Contribuicão ao estudo do paralelismo da flora amazônico-nordestina [Contribution to the study of the paralelism of the amazonian- Nordeste flora] . Inst. Agr. Pernambuco. N. S. Bol. Tec 19, 3-30. [in Portuguese]

Arz H.W., Patzold J., Wefer G., 1999. Climatic changes during the last deglaciation recorded in sediment cores from the northeasternBrazilian Continental Margin. Geo-Marine Letters 19, 209-218.

Auler A.S., Wang X., Edwards R.L., Cheng H., Cristalli P.S., Smart P.L., Richards D.A., 2004. Quaternary ecological and geomorphic changes associated with rainfall events in presently semiarid northeastern Brazil. Jour. Quat. Sci. 19, 693-701.

Baker A., Bradley C., 2010. Modern stalagmite $\delta^{18}$ O: Instrumental calibration and forward modeling. Global and Planetary Change 71, 201-206.

Baker P.A., Fritz S.C., 2015. Nature and causes of Quaternary climate variation of tropical South America.Quaternary Science Reviews 124, 31-47.

Bao Q, Lin P, Zhou T et al., 2013. The Flexible Global Ocean-Atmosphere- Land System Model, spectral version 2: FGOALS-s2. Advances in Atmospheric Sciences 30(3), 561-576.

Bertrand G., Celle-Jeanton H., Loock S., Huneau F., Lavastre V., 2013. Contribution of $\delta^{13}$ CCITD and P $\mathrm{CO}_{\mathrm{eq}}$ measurements to the understanding of groundwater mineralization and carbon patterns in volcanic aquifers. Application to Argnat Basin (Massif Central). Aquatic Geochemistry 19(2): 147-171. DOI: 10.1007/s10498012-9185-0

Bertrand G., Hirata R., Pauwels H., Cary L., Petelet-Giraud E., Chatton E., Aquilina L., Labasque T., Martins V., Montenegro S., Batista J., Aurouet A., Santos J., Bertolo R., Picot G., Franzen M., Hochreutener R., Braibant G., 2016. Groundwater contamination in coastal urban areas: anthropogenic pressure and natural attenuation 
processes. Example of Recife (PE State, NE Brazil). Journal of Contaminant Hydrology 192,165-180. DOI: 10.1016/j.conhyd.2016.07.008

Behling H., Arz H.W., Patzold J., Wefer G.,2000. Late Quaternary vegetational and climate dynamics in northeastern Brazil, inferences from marine core GeoB 3104-1. Quat. Sci. Rev. 19, 981-994.Bush, M.B., Gosling, W.D., Colinvaux, P.A., 2007. Climate Change in the Lowlands of the Amazon Basin. Tropical Rainforest Responses to Climate Change, second ed., pp. 55-76.

Cary L., Petelet-Giraud E., Bertrand G., Martins V., Aurouet A., Montenegro S.., Hirata R., Aquilina L., Pauwels H., Klopmann W., and the COQUEIRAL team, 2015. Origins and mechanisms of groundwater salinization of coastal aquifers in Recife (Brazil). Science of the Total Environment 530-531, 411-429.

Chatton, E.; Aquilina, L.; Petelet-Giraud, E.; Cary, L.; Bertrand, G.; Labasque, T.; Hirata, R., Martins, V., Montenegro, S., Vergnaud, V., Aurouet, A., Kloppmann, W., Pauwels, H., 2016. Glacial recharge, salinization and anthropogenic contamination in the coastal aquifers of Recife (Brazil). Science of the Total Environment 569-570, 1114-1125.

Chatton E., Labasque T., Aquilina L., Hirata R., Petelet-Giraud E., Cary L., Bertrand G. et al., 2015. Assessment of natural dynamics and anthropogenic impacts on residence times in the urban aquifers of Recife (Brazil) using a multi-tracer approach (noble gases, $\mathrm{CFCs}, \mathrm{SF}_{6},{ }^{14} \mathrm{C}$ ). European Geosciences Union General Assembly 2015, Vienna, Austria.

Cheng H., Sinha A., Cruz F.W., Wang X., Edwards R.L., Horta F.M., Ribas C.C., Vuille M., Stott L.D., Auler A.S., 2013. Climate change patterns in Amazonia and biodiversity. Nat Commun 4 : 1411 . doi: $10.1038 /$ ncomms 2415

Clark I., Fritz P., 1997. Environmental Isotopes in Hydrology, CRC Press, Boca Raton, FL.

Coplen T.B. 1995. Discontinuance of SMOW and PDB: Nature 375, 285

Corcho Alvarado, J.A., Leuenberger M., Kipfer R., Paces T., Purtschert, R., 2011. Reconstruction of past climate conditions over central Europe from groundwater data, Quaternary Sci. Rev. 30, 3423-3429.

Craig H., 1961. Isotopic variations in meteoric waters. Science 133, 1702-1703. 
Cruz F.W., Karmann I., Viana O., Burns S.J., Ferrari J.A., Vuille M., Moreira M. Z., Sial A.N.,2005. Stable isotope study of cave percolation waters in subtropical Brazil: implications for paleoclimate inferences from speleothems, Chem. Geol. 220, 245-262.

Cruz F. W., Vuille M., Burns S.J., Wang X., Cheng H., Werner5 R., Edwards L., Karmann I., Auler A.S., Nguyen H., 2009..Orbitally driven east-west antiphasing of South American precipitation. Nat. Geosci. 2, $210-214$.

Dansgaard W., 1964. Stable isotopes in precipitation, Tellus B 16, 436- 468.

Dee S., Noone D., Buenning N., Emile-Geay J., Zhou Y., 2015 SPEEDY-IER: A fast atmospheric GCM with water isotope physics. Journal of Geophysical Research: Atmospheres 120, 73-91, doi:10.1002/2014JD022194

Andrade-Lima D., 1982. Present-day forest refuges in northeastern Brazil. In Biological Diversification in the Tropics, Prance GT (ed.). Columbia University Press: New York; 245-251

Fairchild I.J., Smith C.L., Baker A., Fuller L., Spötl C., Mattey D., McDermott F., E.I.M.F., 2006. Modification and preservation of environmental signals in speleothems. Earth-Science Reviews 75, 105- 153.

Farrera I., Harrison S.P., Prentice I. C., Ramstein G., Guiot J., Bartlein P.J., Bonnefille R., Bush M., Cramer W., von Grafenstein U., Holmgren K., Hooghiemstra H., Hope G., Jolly D., Lauritzen S.E., Ono Y., Pinot S., Stute M., Yu G.,1999. Tropical climates at the Last Glacial Maximum: a new synthesis of terrestrial paleoclimate data. I. Vegetation, lake levels, and geochemistry. Clim. Dyn. 15 (11), 823-856.

Ferrero M.E., Villalba R., DeMembiela M., Hidalgo L.F., Luckman B.H., 2015. Tree-ring based reconstruction of Río Bermejo streamflow in subtropical South America. J. Hydrol. 525, 572-584.

Fontes, J.-C., Gamier, J. M. 1979. Determination of the initial ${ }^{14} \mathrm{C}$ activity of the total dissolved carbon: A review of the existing models and a new approach. Water Resources Research 15: 399-413.

Ford D., Williams P., 2007. Karst Hydrogeology and Geomorphology. John Wiley \& Sons Ltd, The Atrium, Southern Gate, Chichester, England, 562 p.

Gat J.R., Matsui E., 1991. Atmospheric water balance in the Amazon basin: an isotopic evapotranspiration model. J. Geophys. Res. 96, 13179-13188. 
Hogg H.G., Hua Q., Blackwell P.G. Niu M., Buck C.E., Guilderson T.P. Heaton T.J.., Palmer5 J.G. Reimer P.J., Reimer R.W., Turney C.S.M., Zimmerman S.R.H., 2013. SHcal13 Southern Hemisphere Calibration, 0-50,000 Years Cal BP. Radiocarbon 55(4),1889-1903.

IAEA/USGS, 2013. A Laboratory information management system for stable hydrogen and oxygen isotopes in water samples by laser absorption spectroscopy: user manual and tutorial. Revision v 1.5.

IAEA/WMO, 2016. Global network of isotopes in precipitation: The GNIP database. Available via http://wwwnaweb.iaea.org/napc/ih/IHS_resources_gnip.html Jasechko S., Sharp Z.D., Gibson J.J., Birks S.J., Yi Y., Fawcett P.J., 2013. Terrestrial water fluxes dominated by transpiration, Nature 496, 347.

Jiráková H., Huneau F., Celle-Jeanton H., Hrkal Z. Le Coustumer P. L., 2011. Insights into palaeorecharge conditions for European deep aquifers, Hydrogeology J. 19, 1545-1562.

Kageyama M, Braconnot P, Bopp L et al., 2012. Mid-Holocene and last glacial maximum climate simulations with the IPSL model: Part II: Model-data comparisons. Climate Dynamics 40(9-10): 2469-2495.Kluge T., Affek H.P., Marx T., Aeschbach-Hertig W., Riechelmann D.F.C., Scholz D., Riechelmann S. Immenhauser A., Richter D.K., Fohlmeister J., Wackerbarth A., Mangini A. and Spötl C., 2013. Reconstruction of drip-water $\delta^{18} \mathrm{O}$ based on calcite oxygen and clumped isotopes of speleothems from Bunker Cave (Germany). Clim. Past, 9, 377-391.

Kroopnick P.M., Deuser W.G., Graig H., 1970. Carbon-13 measurements on dissolved inorganic carbon in the North Pacific_1969. GEOSECS station. J Geophys Res 75, 7668-7671.

Kurita N., Noone D., Risi C., Schmidt G.A., Yamada H., Yoneyama K., 2011. Intraseasonal isotopic variation associated with the Madden-Julian oscillation, J. Geophys. Res., 116, D24101. doi:10.1029/2010JD015209

Ledru M.P., Soares Braga P.I., Soubies F., Fournier M., Martin L., Suguio K.,. Turcq B., 1996. The last 50,000 years in the Neotropics (Southern Brazil): evolution of vegetation and climate. Palaeogeogr. Palaeoclimatol. Palaeoecol. 123, 239-257.

Ledru M.P., Mourguiart P., Riccomini C., 2009. Related changes in biodiversity, insolation and climate in the Atlantic rainforest since the last interglacial. Palaeogeogr. Palaeoclimatol. Palaeoecol. 271, 140-152.

Lettau, H., Lettau, K., Molion, L.C.B., 1979. Amazonia's hydrologic cycle and the role of atmospheric recycling in assessing deforestation effects. Mon. Weather Reu. 107:227-238. 
Marengo J. A., Liebmann B., Grimm A.M., Misra V., Silva Dias P. L., Cavalcanti I.F.A., Carvalho L.M.V., Berbery E.H., Ambrizzi T., Vera C.S., Saulo A.C., Nogues-Paegle J., Zipser E., Seth A., Alves L.M., 2012. Recent developments on the South American Monsoon system, Int. J. Climatol., 32, 1-21. doi:10.1002/joc.2254, 2012

Marques J., Santos M., Vila Nova N. A., Salati E., 1977. Precipitable water and water vapor flux between Belem and Manaus. Acta Amazonica 7, 355-362.

Masson-Delmotte V., Jouzel J., Landais A., Stievenard M., Johnsen S. J., White J.W. C., Werner M., Sveinbjörnsdottir A., Fuhrer K., 2005. GRIP deuterium excess reveals rapid and orbitalscale changes in Greenland moisture origin, Science 309, 118- 121.

Moquet J.S., Cruz F.W., Novello V.F., Stríkis N.M., Deininger M., Karmann I., Ventura Santos R., Millo C., Apaestegui J., Guyot J.-L., Siffedine A., Vuille M., Cheng H., Edwards R.L., Santini W., 2016. Calibration of speleothem $\delta^{18} \mathrm{O}$ records against hydroclimate instrumental records in Central Brazil. Global and Planetary Change $139,151-164$.

Novello V.F., Cruz F.W., Karmann I., Burns S.J., Strikis N.M., Vuille M., Cheng,H., Edwards R.L., Santos R.V., Frigo E., Barreto E., 2012. Multidecadal climate variability in Brazil's Nordeste during the last 3000 years based on speleothem isotope records. Geophys. Res. Lett. 39, L23706.

Novello V.F., Vuille M., Cruz F.W., Stríkis N.M., Saito de Paula M., Edwards R.L., Cheng H., Karmann I., Jaqueto P.F., Trindade R.I.F., Hartmann G.A., Moquet J.S., 2016. Centennial-scale solar forcing of the South American Monsoon System recorded in stalagmites. Scientific Reports 6:24762. DOI: 10.1038/srep24762

Oliveira P. E., Barreto, A. M. F., Suguiu, K., 1999. Late Pleistocene/Holocene climatic and vegetational history of the Brazilian caatinga: the fossil dunes of the middle São Francisco River. Palaeogeogr. Palaeoclimatol. Palaeoecol. 152, 319-337.

Powell, R.L., Still, C.J., 2009. Biogeography of C3 and C4 vegetation on South America. Anais do XIV Simpósio Brasileiro de Sensoriamento Remoto, pp. 2935-2942 [in Portuguese]

Prado L.F., Wainer I., Chiessi C.M .et al., 2013a. A mid-Holocene climate reconstruction for eastern South America. Climate of the Past 9: 2117-2133. 
Prado L.F., Wainer I., Chiessi C.M. 2013b. Mid-Holocene PMIP3/CMIP5 model results: Intercomparison for the South American Monsoon System. The Holocene 23(12), 1915- 1920.

Risi C., Bony S., Vimeux F., Jouzel J. 2010. Water-stable isotopes in the LMDZ4 general circulation model: Model evaluation for present-day and past climates and applications to climatic interpretations of tropical isotopic records, J. Geophys. Res. 115, D12118. doi:10.1029/2009JD013255.

Rizzini C.T., 1967. Delimitação, caracterização e relaçoes da flora silvestre hileiana [Delimitation, characteriation and relationshiphs of the wild hileiana flora]. Atlas Simp. Biota Amazônica 4 (Botânica), pp. 13-36. [in Portuguese]

Rozanski K., 1985. Deuterium and oxygen-18 in European groundwaters - links to atmospheric circulation in the past, Chem. Geol. 52, 349-363.

Rozanski K., Araguas-Araguas L., Gonfiantini R., 1993. Isotopic patterns in modem global precipitation, in: Climate Change in Continental Isotopic Records - Geophysical Monograph 78, edited by: Swart P. K., Lohman K. C., McKenzie J., Savin S., American Geophysical Union, Washington, DC, pp 1-36.

Rozanski K., Johnsen S. J., SchottererU., Thompson, L. G., 1997. Reconstruction of past climates from stable isotope records of palaeo-precipitation preserved in continental archives. Hydrological Sciences Journal 42 (5), $725-745$

Salati E.; Dall'olio A.; Matsui E., Gat J. R., 1979. Recycling of Water in the Amazon Basin: An Isotopic Study. Water Resour Research 15 (5), 1250-1258.

Santos T.P., et al., 2014. Paleoceanographic reconstruction of the western equatorial Atlantic during the last 40 kyr. Palaeogeogr. Palaeoclimatol. Palaeoecol. 415, 14-20.

Silva Dias P.L., Turcq B., Silva Dias M. A. F., Braconnot P., Jorgetti T. 2009. Mid-Holocene climate of tropical South America: a model-data approach. In Vimieux F., Sylvestre F., Khodri M (Eds.), Past Climate Variability in South America and Surrounding Regions. From the Last Glacial Maximum to the Holocene, vol. 14., Springer Netherlands

Sereffiddin F., Schwarcz H.P., Ford D., Baldwin S., 2004. Late Pleistocene paleoclimate in the Black Hills of South Dakota from isotope records in speleothems. Palaeogeography, Palaeoclimatology, Palaeoecology 203, 1-17. 
Sifeddine A., Meyer P., Cordeiro R.C., Albuquerque A.L.S., Bernardes M., Turcq B., Abrao J.J., 2011. Delivery and deposition of organic matter in surface sediments of Lagoa do Caçó (Brazil). J. Paleolimnol. 45, 385-396.

Steffensen J. P., Andersen K. K., Bigler M., Clausen H. B., Dahl- Jensen D., Fischer H., Goto-Azuma K., Hansson M., Johnsen S. J., Jouzel J., Masson-Delmotte V., Popp T., Rasmussen S. O., Roethlisberger R., Ruth U., Stauffer B., Siggaard-Andersen M.-L., Sveinbjornsdottir A. E., Svensson A., White J. W. C., 2008. Highresolution Greenland Ice Core data show abrupt climate change happens in few years. Science,321, 680-684.

Stuiver M., Reimer P. J., Reimer R. W., 2005. CALIB 5.0. Available via http://calib.qub.ac.uk/calib/ Accessed 20/06/2015

Stute M., Forster M., Frischkorn H., Serejo A., Clark J. F., Schlosser P., et al., 1995. Cooling of Tropical Brazil (5 degrees C) during the Last Glacial Maximum. Science, 269(5222), 379-383.

Sylvestre F. 2009. Moisture Pattern During the Last Glacial Maximum in South America. In Vimieux F., Sylvestre F., Khodri M (Eds.) Past Climate Variability in South America and Surrounding Regions. From the Last Glacial Maximum to the Holocene, vol. 14., Springer Netherlands.

Thompson L.G., Mosley-Thompson E., Davis M.E., Zagorodnov V.S., Howat I.M., Mikhalenko V.N., Lin P.N., 2013. Annually Resolved Ice Core Records of Tropical Climate Variability over the Past $\sim 1800$ Years . Science 340, 945-950.

Toth J., 1963. A theoretical analysis of groundwater flow in small drainage basins. J Geophys Res 68(16):4785-4812

Valdes P.J., 2000. South American paleoclimate model simulations: How reliable are the models? J. Quat. Sci. 15(4), 357-368.

Vera C., Higgins W., Amador J., Ambrizzi T., Garreaud R., Gochis D., Gutzler D., Lettenmaier D., Marengo J., Mechoso C. R., Nogues-Paegle J., Silva Dias P. L., Zhang C., 2006. Toward a unified view of the American Monsoon Systems, J. Climate 19, 4977-5000.

Viana J.C.C., Sifeddine A., Turcq B., Albuquerque A.L.S., Moreira L.S., Gomes D.F., Cordeiro R.C., 2014. A late Holocene paleoclimate reconstruction from Boqueirão Lake sediments, northeastern Brazil. Palaeogeography, Palaeoclimatology, Palaeoecology 415, 117-126. 
Villalba R., Grosjean M., Kiefer T., 2009. Long-term multi-proxy climate reconstructions and dynamics in South America(LOTRED-SA): State of the art and perspectives. Palaeogeography, Palaeoclimatology, Palaeoecology $281,175-179$.

Vimeux F., Ginot P., Schwikowski M., Vuille M., Hoffmann G., Thompson L.G., Schotterer U., 2009. Climate variability during the last 1000 years inferred from Andean ice cores: a review of recent results, Palaeogeography, Palaeoclimatology, Palaeoecology 281, 229-241.

Voldoire A., Sanchez-Gomes E., Salas y Melia D. et al., 2013. The CNRMCM5.1 global climate model: Description and basic evaluation. Climate Dynamics 40 (9-10), 2091-2121.

Vogel, J. C., 1970.Carbon-14 dating of groundwater, in Isotope Hydrology pp. 235-237, International Atomic Energy Agency, Vienna,

Vuille M., Burns S.J., Taylor B.L., Cruz F.W., Bird B.W., Abbott M.B., Kanner L.C., Cheng H., Novello V.F.2012. A review of the South American monsoon history as recorded in stable isotopic proxies over the past two millennia. Clim. Past 8, 1309-1321.

World Meteorological Organization (2013). http://worldweather.wmo.int/136/c01078.htm\#climate

Accessed 30/11/2016

Wang X., Auler A.S., Edwards R.L.., Cheng H., Cristalli P.S.,, Smart P.L.,, Richards D.A.,Shen C.C., 2004. Wet periods in northeastern Brazil over the past 210 kyr linked to distant climate anomalies. Nature 432, 740-743.

Watanabe S., Hajima T., Sudo K. et al. 2011. MIROC-ESM 2010: Model description and basic results of CMIP520c3m experiments. Geoscientific Model Development 4, 845-872.

Werner M., Haese B., Xu X., Zhang X., Butzin M., Lohmann G. 2016. Glacial-interglacial changes in $\mathrm{H}_{2}{ }^{18} \mathrm{O}$, HDO and deuterium excess - results from the fully coupled ECHAM5/MPI-OM Earth system model. Geosci. Model Dev. 9, 647-670.

Xin X.G., Wu T.W., Zhang J., 2013. Introduction of CMIP5 experiments carried out with the climate system models of Beijing Climate Center. Advances in Climate Change Research 4(1), 41-49. 
Zimmerman U., Ehhalt D., Munnich K.O., 1967. Soil water movement and evapotranspiration: changes in the isotopic composition of the water. In Isotopes in Hydrology, Proceedings of the Symposium. I.A.E.A.: Vienna: $567-584$

Zocatelli R., Turcq B., Boussafir M., Cordeiro R.C., Disnar J.R., Costa R.L., Sifeddine A., Albuquerque A.L.S., Bernardes M.C., Jacob J., 2012. Late Holocene paleoenvironmental changes in Northeast Brazil recorded by organic matter in lacustrine sediments of Lake Boqueirão. Palaeogeography, Palaeoclimatology, Palaeoecology $363-364,127-134$. 


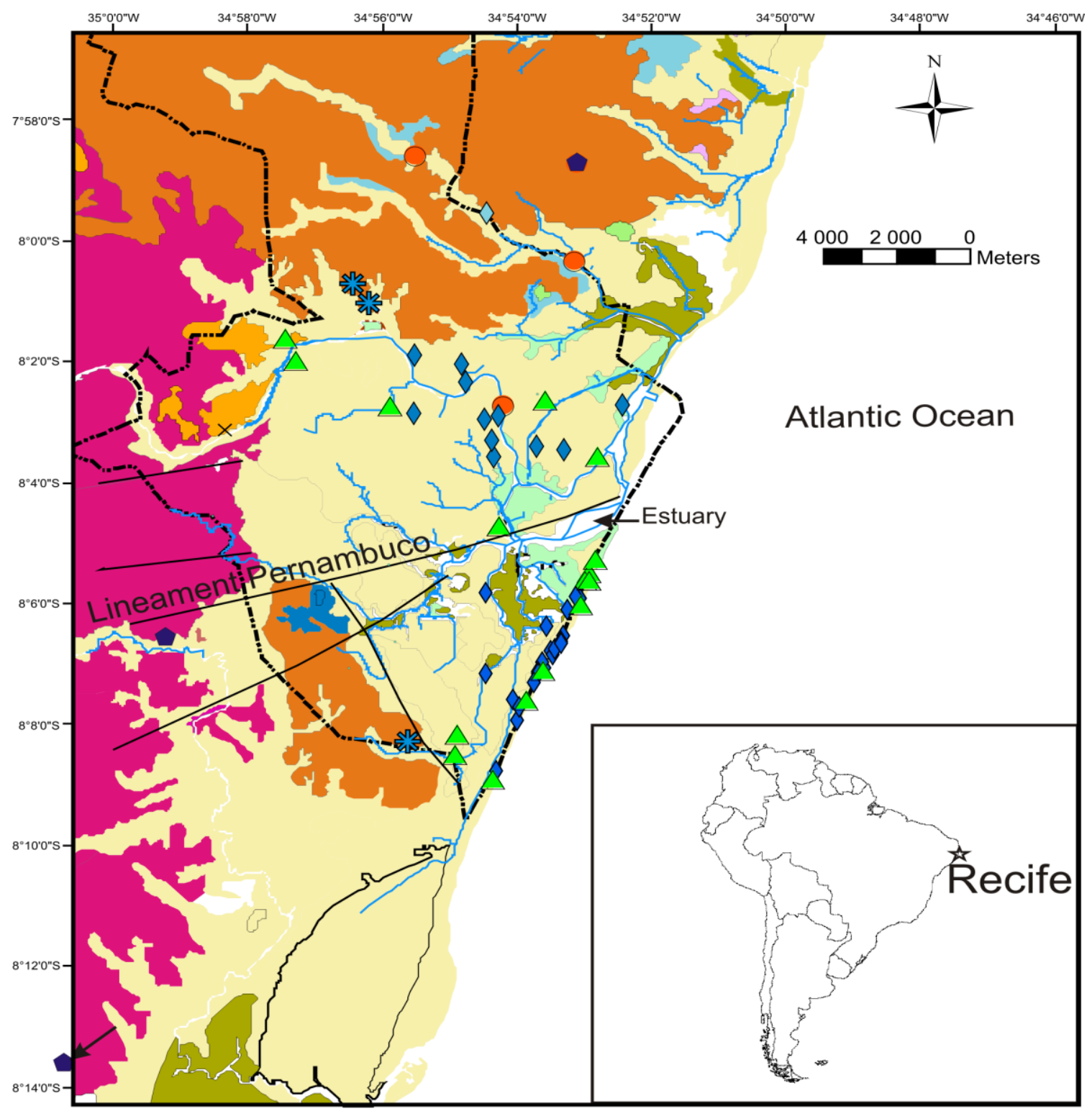

Boa Viagem aquifer system

$\square$ Alluvial dep.; Fluvio-lagoon dep., Holoc. to Pleiost. beach dep. Mangrove sed.

Barreiras aquifer system (Pliocene, Siliciclastic dominated sediments)

(1)

Beberibe aquifer system (Cretaceous sediments of continental and marine origins)

Con

Cabo system (Cretaceous sediments of continental and marine origins)

$\square$

Crystalline Basement (Granites, Gneiss, Leucogranites, granodiorites, quartzodiorites, syenites)
Sampling points

Surface waters

Surface water reservoir

(Recife's water supply network)

A Boa Viagem

福 Barreiras

\ Cabo (South Pern. lineament)

$\checkmark$ Beberibe (North Pern. lineament)

Recife city limit

23

Figure 1 


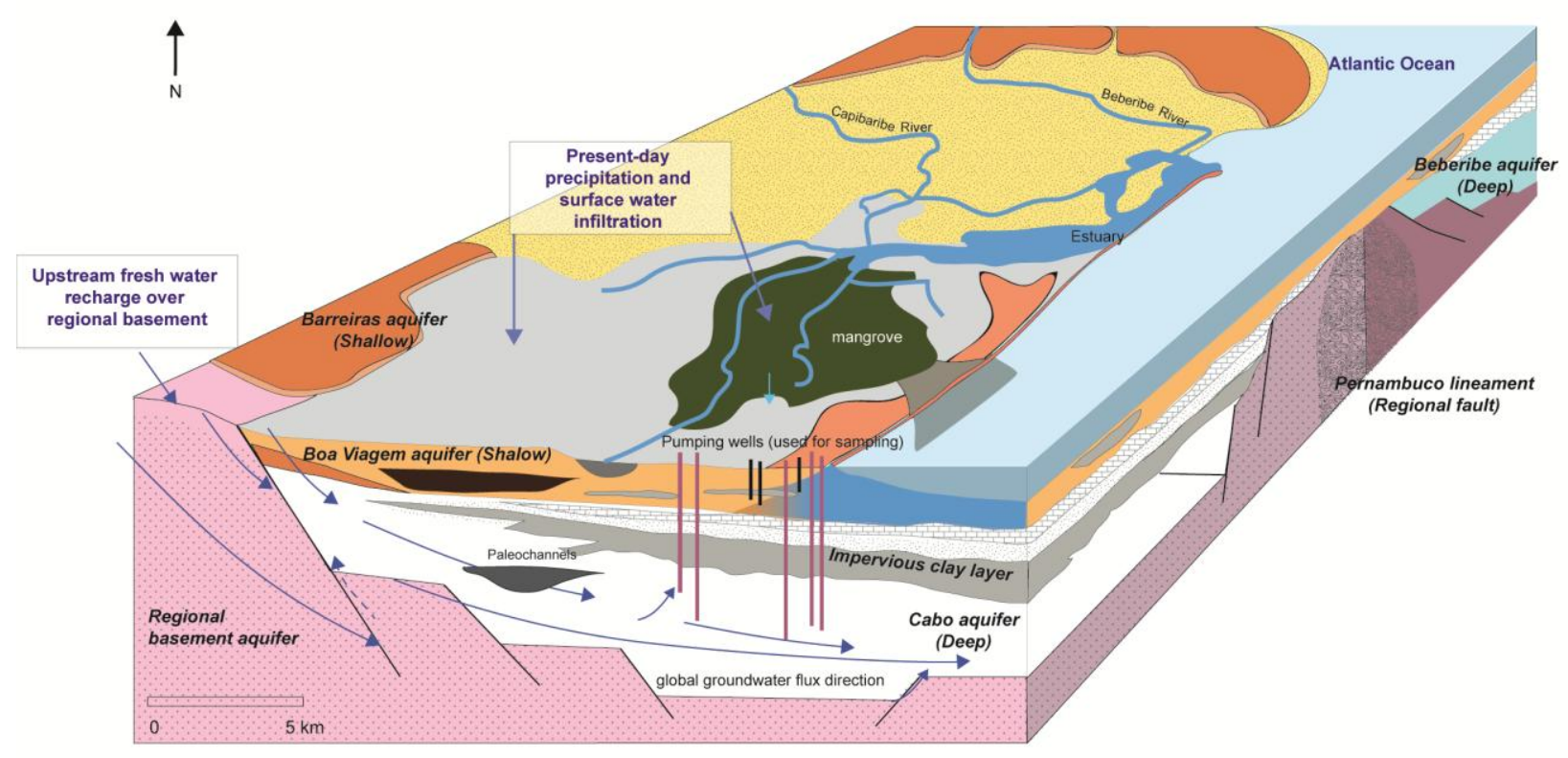

Figure 2 

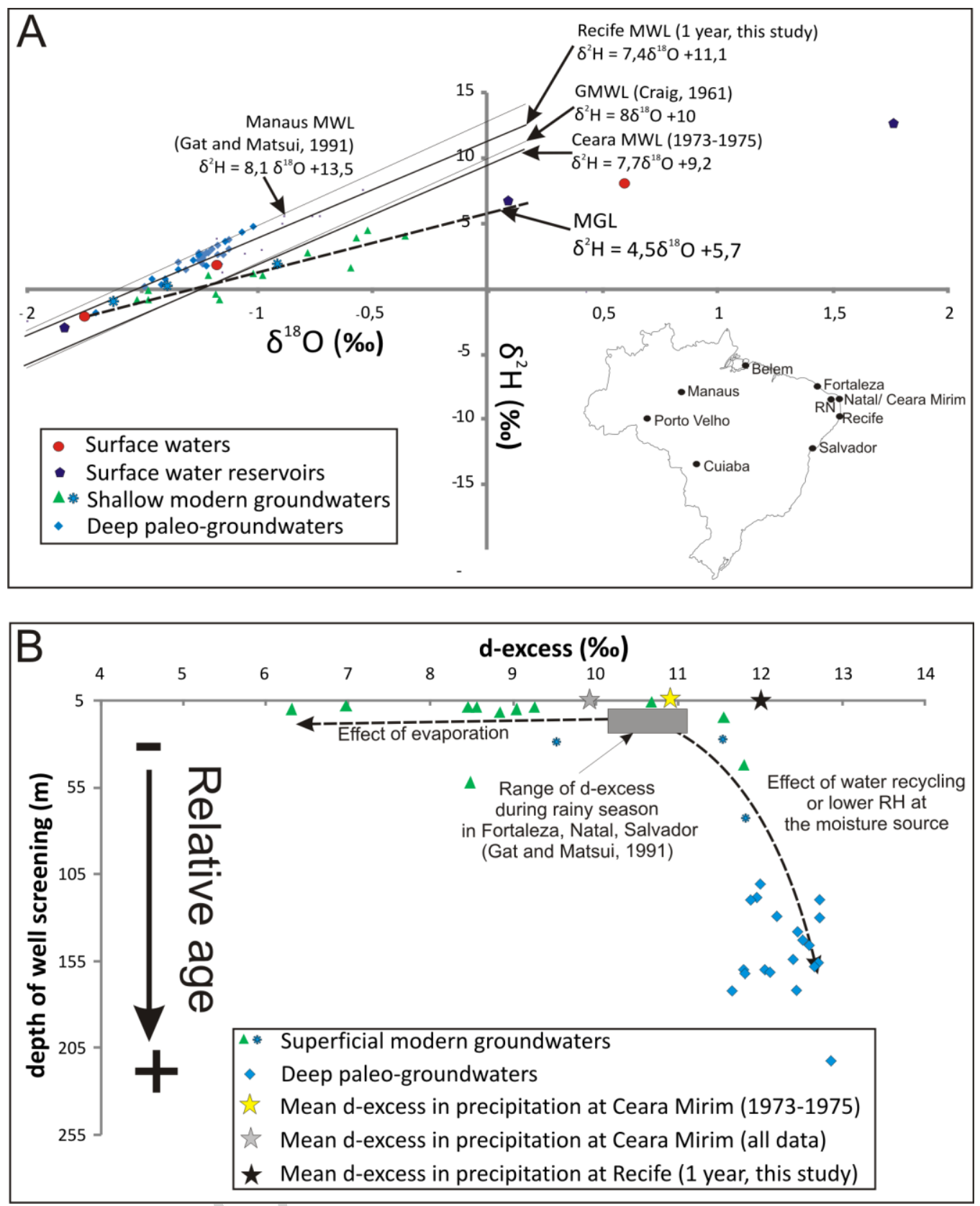

Figure 3 


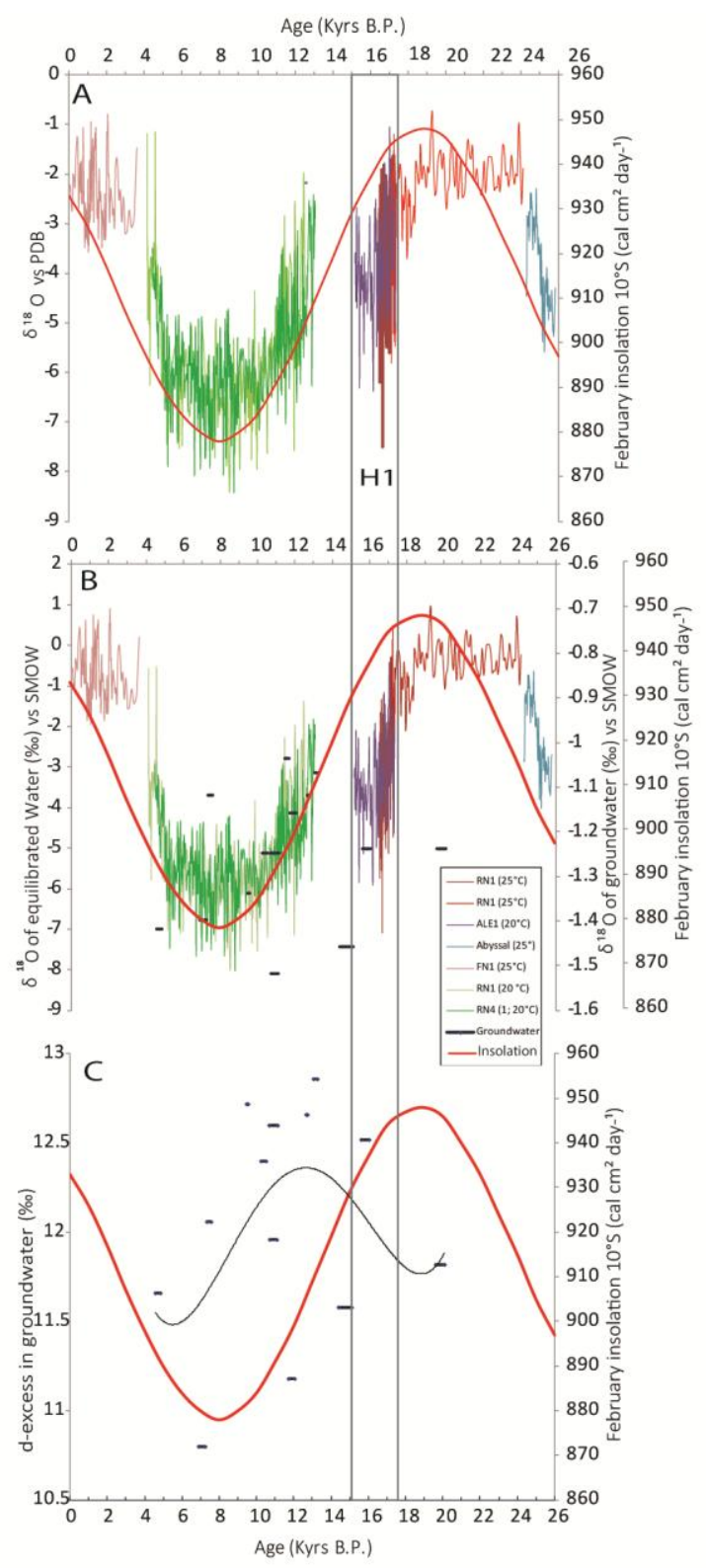

Figure 4 

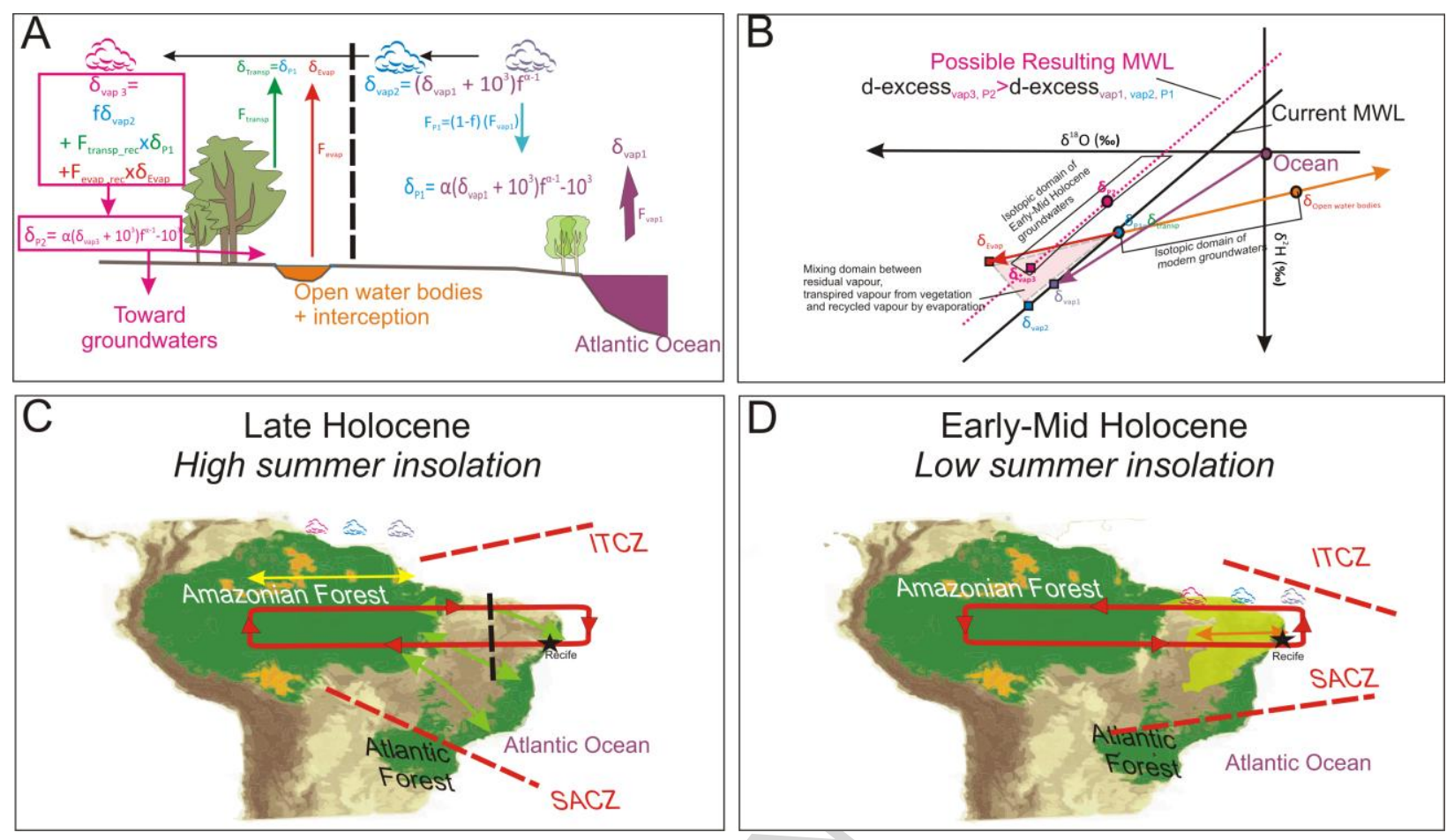

Figure 5 


\section{Figure captions}

Figure 1:Localization and geological map of the area.

Figure 2: Conceptual sketch of the aquifer systems.

Figure 3: $\mathrm{A} . \delta^{18} \mathrm{O} v s \delta^{2} \mathrm{H}$ diagram. Shallow (Boa Viagem/Barreiras) and deep (Cabo/Beberibe) groundwater samples are reported as well as The Global Meteoric Water line (Craig, 1961), the Local Meteoric Water Line performed during the hydrogeological study (Cary et al., 2015) and the Manaus water line reported by Gat and Matsui (1991). Modern Groundwater Line corresponds to the shallow groundwater affected by kinetically evaporated source which are attributed to the local channel infiltration. Note that the deep groundwater plot above the LMWL. B. Deuterium excess d vs well screening depth.

Figure 4: Comparison of $\delta^{18} \mathrm{O}$ trends between Rio Grande do Norte cave calcite (Cruz et al., 2009) and Recife dated deep groundwaters (Cabo/Beberibe). A. Original Cruz et al.'s $\delta^{18} \mathrm{O}$ speleothem records in Rio Grande do Norte (note that $\delta^{18} \mathrm{O}$ are expressed vs $\left.\mathrm{PDB}\right)$. B. Calculated $\delta^{18} \mathrm{O}$ of drip water assuming an isotopic equilibrium between carbonate and drip water (using equation reported in Kluge et al. [2013] and assuming an equilibrium temperature of $25^{\circ} \mathrm{C}$ between 0 and 12,5 kyrs B.P (corresponding to the mean annual temperature in Rio Grande do Norte; Cruz et al., 2009). and of $20^{\circ} \mathrm{C}$ between 12,5 and 26 kyrs accordingly with the $5^{\circ} \mathrm{C}$ difference between these two period suggested by Stute et al. (1995). Comparison with ${ }^{14} \mathrm{C}$ dated Recife's deep groundwater (note that all $\delta^{18} \mathrm{O}$ are expressed vs SMOW; $\delta^{18} \mathrm{O}(\mathrm{vs}$ VSMOW $)=1.03092\left[\delta^{18} \mathrm{O}(\mathrm{VPDB})\right]+30.92$; Coplen, 1995). C. Corresponding dexcess for the ${ }^{14} \mathrm{C}$ dated Recife's deep groundwater. Note that although the number of data is limited and that an outlier is identified, possibly linked with high frequency and temporary ecological shifts (Oliveira et al., 1999), dexcess seems to reversely follow the insolation pattern with a time-lag. More data would be necessary to confirm this general trend. $\mathrm{H} 1$ refers to the Heinrich event 1 characterized by depleted $\delta^{18} \mathrm{O}$ in the Rio Grande do Norte cave calcite.

Figure 5 A. Conceptual scheme of moisture and isotopic patterns for northern tropical SA, and potentially occurring during early-Mid Holocene period (modified after Dansgaard, 1964; Gat and Matsui, 1991). a represent fractionation factor between vapor and liquid. $f$ represent the remaining fraction of the initial content of vapor in the air-mass (Rayleigh distillation model) B. Same processes represented in the $\delta^{18} \mathrm{O}$ vs $\delta^{2} \mathrm{H}$ domain. C and D. Conceptual schemes of (paleo)climatological and ecological process during Late and Early-Mid Holocene (adapted 
from Cruz et al., 2009 and Auler et al., 2004). In a context of increased rainfall due to ITCZ location shift, the setting of transitional ecosystems (firstly hypothesized as narrow corridors represented by lime green arrows, but possibly widespread according to Auler et al. [2004]) between Amazonian Forest and Atlantic Forest, favoring open water bodies and interception evaporation, could have promoted recycling of water, what leads to a modified meteoric water line and higher d-excess. Symbols: $\varepsilon$ : equilibrium enrichment factor; F: fraction of contribution from evaporation or transpiration to the clouds. f: remaining fraction of water within the clouds according to the Rayleigh distillation model (cf. Clark and Fritz, 1997). 
Table 1

\begin{tabular}{|c|c|c|c|c|c|c|c|}
\hline Sample & $\begin{array}{l}X(\mathrm{~m}) \\
\text { [WGS } \\
84 ; 10 S]\end{array}$ & $\begin{array}{c}\mathrm{Y}(\mathrm{m}) \\
{[\mathrm{WGS} 84 ;} \\
10 \mathrm{~S}]\end{array}$ & $\begin{array}{l}\text { Type of } \\
\text { sample }\end{array}$ & $\begin{array}{c}\delta^{18} \mathrm{O}(\% \circ \\
\text { vs } \\
\text { VSMOW) }\end{array}$ & $\begin{array}{c}\delta^{2} \mathrm{H}(\% \circ \\
\text { vs } \\
\text { VSMOW) }\end{array}$ & d excess & $\begin{array}{c}\text { Temp } \\
\left({ }^{\circ} \mathrm{C}\right) \\
\text { (Chatton } \\
\text { et al., } \\
\text { 2016) }\end{array}$ \\
\hline ALM 73 & 287507 & 9109986 & Deep Gw & $-1,4$ & 0 & 10.8 & 19.7 \\
\hline TTD94 & 289358 & 9102059 & Deep Gw & -1.5 & 0 & 11.96 & 14.8 \\
\hline TTD110 & 289358 & 9102059 & Deep Gw & -1.5 & 0 & 11.58 & 18 \\
\hline CAB2 & 290567 & 9100530 & Deep Gw & $-1,3$ & 3 & 12,7 & 16.8 \\
\hline Cab03 & 291286 & 9102344 & Deep Gw & $-1,2$ & 2 & 11,82 & 14.8 \\
\hline CAB4 & 291499 & 9102653 & Deep Gw & $-1,3$ & 1 & 11,88 & 15.7 \\
\hline CAB5 & 289684 & 9104426 & Deep Gw & $-1,2$ & & 11,18 & \\
\hline CAB6 & 291373 & 9103389 & Deep Gw & $-1,2$ & 3 & 12,48 & \\
\hline CAB10 & 291165 & 9102037 & Deep Gw & $-1,2$ & 3 & 11,8 & 18.6 \\
\hline CAB11 & 291135 & 9101975 & Deep Gw & $-1,2$ & 3 & 12,46 & 17.4 \\
\hline CAB12 & 289992 & 9099014 & Deep Gw & $-1,3$ & 2 & 12,72 & 17.3 \\
\hline CAB13 & 290468 & 9101191 & Deep Gw & $-1,2$ & 2 & 12,22 & \\
\hline Cab17 & 291806 & 9103117 & Deep Gw & $-1,1$ & 3 & 12,06 & 14.3 \\
\hline CAB20 & 290617 & 9100953 & Deep Gw & $-1,5$ & 0 & 12,12 & 17.9 \\
\hline CAB22 & 291014 & 9101692 & Deep Gw & $-1,3$ & 2 & 12,2 & \\
\hline CAB23 & 291922 & 9103914 & Deep Gw & $-1,2$ & 3 & 12,44 & 19.4 \\
\hline Cab24 & 292190 & 9104320 & Deep Gw & $-1,3$ & 2 & 12,4 & 20.6 \\
\hline CAB26 & 291545 & 9102585 & Deep Gw & $-1,2$ & 2 & 12,22 & 14.8 \\
\hline Cab27 & 291630 & 9102732 & Deep Gw & $-1,2$ & 3 & 12,52 & 14.4 \\
\hline Cab36 & 290069 & 9106520 & Deep Gw & $-1,1$ & 4 & 12,66 & 18 \\
\hline CAB 101 & 291746 & 9102955 & Deep Gw & $-1,2$ & 3 & 12,66 & \\
\hline CAB102 & 291746 & 9102887 & Deep Gw & $-1,2$ & 3 & 12,6 & 14.2 \\
\hline CAB114 & 289726 & 9101999 & Deep Gw & $-1,2$ & 3 & 11,96 & 14.8 \\
\hline BEB131 & 289150 & 9111308 & Deep Gw & $-1,2$ & 2 & 11,46 & \\
\hline BEB132 & 289753 & 9115980 & Deep Gw & $-1,7$ & -2 & 11,8 & \\
\hline BEB47 & 287812 & 9111792 & Deep Gw & $-1,5$ & 1 & 12,38 & \\
\hline
\end{tabular}




\begin{tabular}{|c|c|c|c|c|c|c|c|}
\hline BEB50 & 291777 & 9108799 & Deep Gw & $-1,1$ & 4 & 12,72 & 14.1 \\
\hline BEB51 & 289907 & 9109036 & Deep Gw & $-1,4$ & 1 & 12 & 18.6 \\
\hline BEB52 & 289195 & 9110846 & Deep Gw & $-1,3$ & 2 & 12,44 & \\
\hline BEB57 & 291029 & 9108891 & Deep Gw & $-1,3$ & 3 & 12,6 & 14.5 \\
\hline BEB59 & 289781 & 9109798 & Deep Gw & $-1,4$ & 0 & 11,66 & 22.2 \\
\hline BEB60 & 290047 & 9109897 & Deep Gw & $-1,3$ & 1 & 12,12 & 25.1 \\
\hline BEB62 & 293372 & 9110177 & Deep Gw & $-1,1$ & 4 & 12,86 & 15.4 \\
\hline BAR120 & 287167 & 9102952 & Sup. Gw & $-1,5$ & 0 & 11,84 & \\
\hline BAR121 & 291089 & 9110512 & Sup. Gw & $-2,0$ & -3 & 13,06 & 19 \\
\hline BAR124 & 287964 & 9099662 & Sup. Gw & $-1,6$ & -1 & 11,82 & \\
\hline BAR64 & 287013 & 9105315 & Sup. Gw & $-1,0$ & 2 & 9,48 & \\
\hline BAR068B & 282201 & 9106787 & Sup. Gw & $-1,4$ & 0 & 11,34 & \\
\hline BOV100 & 292531 & 9104842 & Sup. Gw & $-0,6$ & 2 & 6,32 & 17 \\
\hline BOV110 & 292677 & 9105500 & Sup. Gw & $-0,4$ & 4 & 6,98 & 21 \\
\hline BOV111 & 289909 & 9098783 & Sup. Gw & $-0,8$ & 3 & 8,94 & \\
\hline BOV112 & 290790 & 9101194 & Sup. Gw & $-1,0$ & 1 & 8,84 & 21 \\
\hline BOV113 & 291257 & 9102098 & Sup. Gw & $-0,5$ & 4 & 8,56 & 23 \\
\hline BOV115 & 288908 & 9100152 & Sup. Gw & $-1,5$ & -1 & 10,96 & 36 \\
\hline Bov116 & 288833 & 9099503 & Sup. Gw & $-1,5$ & -1 & 11,26 & \\
\hline BOV130 & 291341 & 9110333 & Sup. Gw & $-1,5$ & 0 & 11,56 & 27 \\
\hline BOV14 & 292544 & 9105097 & Sup. Gw & $-1,0$ & 1 & 9,26 & 30 \\
\hline BOV30 & 287081 & 9110200 & Sup. Gw & $-1,2$ & 0 & 9,04 & 25 \\
\hline BOV33 & 284227 & 9112236 & Sup. Gw & $-1,8$ & -2 & 11,8 & 19 \\
\hline BOV46 & 292757 & 9108650 & Sup. Gw & $-1,2$ & 1 & 10,68 & \\
\hline BOV34 & 284484 & 9111567 & Sup. Gw & $-1,2$ & -1 & 8,48 & 21 \\
\hline BOV19 & 292400 & 9104840 & Sup. Gw & $-0,6$ & 4 & 8,46 & 23 \\
\hline RIVBEB1 & 292132 & 9114584 & Surf. Wat. & $-1,7$ & -2 & 11,72 & \\
\hline RIVBEB2 & 287787 & 9117827 & Surf. Wat. & $-1,2$ & 2 & 11,06 & \\
\hline RIVCAP & 290170 & 9110195 & Surf. Wat. & 0,6 & 8 & 3,3 & \\
\hline ETA200 & 291493 & 9113938 & Surf. Wat. & $-1,8$ & -3 & 11,64 & \\
\hline ETA201 & 280903 & 9106726 & Surf. Wat. & 1,7 & 14 & $-0,26$ & \\
\hline ETA202 & 274279 & 9085417 & Surf. Wat. & 0,1 & 7 & 5,98 & \\
\hline
\end{tabular}


Table 2

\begin{tabular}{|c|c|c|c|c|c|c|c|c|c|c|c|c|c|c|c|c|c|c|c|}
\hline Well & $\begin{array}{l}\mathbf{O} \\
2\end{array}$ & $\begin{array}{l}\text { Con } \\
\text { duct } \\
\text { ivity }\end{array}$ & pH & $\mathbf{T}^{\circ} \mathbf{C}$ & $\mathrm{Ca}$ & Mg & $\mathrm{Na}$ & $\mathbf{K}$ & Cl & $\begin{array}{c}\text { HC } \\
\text { O3 }\end{array}$ & $\mathrm{SO}_{4}$ & $\mathrm{NO}_{3}$ & $\mathrm{NO}_{2}$ & $\begin{array}{c}\delta^{13} \mathbf{C} \\
(\mathrm{TDI} \\
\mathbf{C}) \\
(\%)\end{array}$ & $\begin{array}{c}\text { Calc } \\
\text { ulat } \\
\text { ed } \\
\delta^{13} \mathbf{C} \\
(\mathbf{e q C} \\
\left.\mathrm{O}_{2}\right) \\
(\%)\end{array}$ & $\begin{array}{c}\text { a_C } \\
\mathbf{1 4} \\
(\mathbf{p m} \\
\mathrm{C})\end{array}$ & $\underset{14}{\mathbf{a}_{14} C}$ & $\begin{array}{c}\text { lowe } \\
\text { r } \\
\text { rang } \\
\text { e } \\
\text { age } \\
\text { C14 } \\
\text { cal } \\
\text { age } \\
\text { (Kyr } \\
\text { s } \\
\text { BP) }\end{array}$ & $\begin{array}{c}\text { upp } \\
\text { er } \\
\text { rang } \\
\text { e } \\
\text { C14 } \\
\text { cal } \\
\text { age } \\
\text { (Kyr } \\
\text { s } \\
\text { BP) }\end{array}$ \\
\hline $\begin{array}{c}\text { BEB- } \\
057\end{array}$ & $\begin{array}{l}2 . \\
2\end{array}$ & 824 & 5.9 & 31.3 & $\begin{array}{c}41.3 \\
3\end{array}$ & $\begin{array}{c}28.6 \\
2 \\
\end{array}$ & $\begin{array}{c}57.3 \\
3 \\
\end{array}$ & $\begin{array}{c}24.5 \\
3 \\
\end{array}$ & $\begin{array}{c}204 . \\
58\end{array}$ & $\begin{array}{c}35.2 \\
8 \\
\end{array}$ & $\begin{array}{c}32.5 \\
2 \\
\end{array}$ & 0.17 & 0.08 & -19.7 & -21.0 & $\begin{array}{c}30.3 \\
0\end{array}$ & 0.19 & $\begin{array}{c}10.6 \\
8\end{array}$ & $\begin{array}{c}11.1 \\
4\end{array}$ \\
\hline $\begin{array}{c}\text { BEB- } \\
059\end{array}$ & $\begin{array}{l}2 . \\
43\end{array}$ & 945 & 6.09 & 29.7 & $\begin{array}{c}19.9 \\
7\end{array}$ & $\begin{array}{c}25.3 \\
4\end{array}$ & $\begin{array}{c}115 . \\
47\end{array}$ & $\begin{array}{c}30.8 \\
2\end{array}$ & $\begin{array}{c}210 . \\
93\end{array}$ & $\begin{array}{c}133 . \\
77\end{array}$ & $\begin{array}{c}11.4 \\
1\end{array}$ & 1.03 & 0.09 & -7.2 & -9.3 & $\begin{array}{c}59.1 \\
0\end{array}$ & 0.21 & 4.57 & 4.85 \\
\hline $\begin{array}{c}\text { BEB- } \\
062\end{array}$ & $\begin{array}{l}3 . \\
03\end{array}$ & 239 & 5.86 & 32.8 & 3.94 & 3.60 & $\begin{array}{c}19.6 \\
6 \\
\end{array}$ & $\begin{array}{c}11.5 \\
1 \\
\end{array}$ & $\begin{array}{c}28.7 \\
2\end{array}$ & $\begin{array}{c}35.2 \\
8 \\
\end{array}$ & $\begin{array}{c}11.4 \\
3 \\
\end{array}$ & 0.16 & 0.01 & -15.6 & -16.7 & $\begin{array}{c}24.4 \\
0 \\
\end{array}$ & 0.15 & $\begin{array}{c}13.0 \\
5\end{array}$ & $\begin{array}{c}13.2 \\
8 \\
\end{array}$ \\
\hline $\begin{array}{c}\text { CAB- } \\
003\end{array}$ & $\begin{array}{l}1 . \\
01\end{array}$ & 262 & 6.25 & 31.3 & 3.39 & 3.31 & $\begin{array}{c}43.6 \\
4 \\
\end{array}$ & 6.74 & $\begin{array}{c}23.4 \\
9 \\
\end{array}$ & $\begin{array}{c}91.1 \\
5 \\
\end{array}$ & 8.22 & 0.18 & 0.02 & -18.8 & -14.0 & $\begin{array}{c}12.8 \\
0 \\
\end{array}$ & 0.11 & $\begin{array}{c}19.6 \\
2 \\
\end{array}$ & $\begin{array}{c}20.1 \\
0 \\
\end{array}$ \\
\hline $\begin{array}{c}\text { CAB- } \\
005\end{array}$ & $\begin{array}{c}1 . \\
06\end{array}$ & 5063 & 6.48 & 30.4 & $\begin{array}{c}130 . \\
55 \\
\end{array}$ & $\begin{array}{c}119 . \\
38 \\
\end{array}$ & $\begin{array}{c}589 . \\
44 \\
\end{array}$ & $\begin{array}{c}23.6 \\
6 \\
\end{array}$ & $\begin{array}{c}1402 \\
.67 \\
\end{array}$ & $\begin{array}{c}111 . \\
73\end{array}$ & $\begin{array}{c}170 . \\
89 \\
\end{array}$ & 0.77 & 0.11 & -14.9 & -21.6 & $\begin{array}{c}27.9 \\
0 \\
\end{array}$ & 0.10 & $\begin{array}{c}11.7 \\
2 \\
\end{array}$ & $\begin{array}{c}12.0 \\
5 \\
\end{array}$ \\
\hline $\begin{array}{c}\text { CAB- } \\
012\end{array}$ & $\begin{array}{c}0 . \\
6 \\
\end{array}$ & $\begin{array}{c}224 . \\
3\end{array}$ & 6 & 30.5 & 1.48 & 1.67 & $\begin{array}{c}34.8 \\
0 \\
\end{array}$ & 7.83 & $\begin{array}{c}17.6 \\
7 \\
\end{array}$ & $\begin{array}{c}49.9 \\
9\end{array}$ & $\begin{array}{c}15.6 \\
4\end{array}$ & 0.28 & 0.03 & -11.4 & -18.8 & $\begin{array}{c}34.4 \\
0 \\
\end{array}$ & 0.10 & 9.47 & 9.55 \\
\hline $\begin{array}{c}\text { CAB- } \\
017\end{array}$ & $\begin{array}{l}1 . \\
1\end{array}$ & 2560 & 6.1 & 30.8 & $\begin{array}{c}60.4 \\
7\end{array}$ & $\begin{array}{c}55.3 \\
4\end{array}$ & $\begin{array}{c}298 . \\
50\end{array}$ & $\begin{array}{c}20.1 \\
8\end{array}$ & $\begin{array}{c}724 . \\
13\end{array}$ & $\begin{array}{c}41.1 \\
6\end{array}$ & $\begin{array}{c}88.5 \\
0\end{array}$ & 0.58 & 0.06 & -19.5 & -13.1 & $\begin{array}{c}28.9 \\
0\end{array}$ & 0.22 & 7.33 & 7.57 \\
\hline $\begin{array}{c}\text { CAB- } \\
024\end{array}$ & $\begin{array}{l}2 . \\
68\end{array}$ & 950 & 5.99 & 31.2 & $\begin{array}{c}25.7 \\
1 \\
\end{array}$ & $\begin{array}{c}22.7 \\
1\end{array}$ & $\begin{array}{c}120 . \\
43\end{array}$ & $\begin{array}{c}19.8 \\
4 \\
\end{array}$ & $\begin{array}{c}237 \\
65\end{array}$ & $\begin{array}{c}47.7 \\
8 \\
\end{array}$ & $\begin{array}{c}41.7 \\
7 \\
\end{array}$ & 0.33 & 1.10 & -17.7 & -21.6 & $\begin{array}{c}44.0 \\
0 \\
\end{array}$ & 0.15 & $\begin{array}{c}10.2 \\
4\end{array}$ & $\begin{array}{c}10.5 \\
2\end{array}$ \\
\hline $\begin{array}{c}\text { CAB- } \\
027\end{array}$ & $\begin{array}{c}. \\
09\end{array}$ & 237 & 6.3 & 32.1 & 3.70 & 3.47 & $\begin{array}{c}39.5 \\
0\end{array}$ & 6.20 & $\begin{array}{c}19.5 \\
7\end{array}$ & $\begin{array}{c}77.9 \\
2\end{array}$ & $\begin{array}{c}10.3 \\
3\end{array}$ & 0.15 & 0.03 & -17.1 & -19.3 & $\begin{array}{c}19.3 \\
0\end{array}$ & 0.10 & $\begin{array}{c}15.6 \\
2\end{array}$ & $\begin{array}{c}16.0 \\
5\end{array}$ \\
\hline $\begin{array}{c}\text { CAB- } \\
036\end{array}$ & $\begin{array}{c}1 . \\
25\end{array}$ & 818 & 6.2 & 30 & $\begin{array}{c}26.5 \\
4 \\
\end{array}$ & $\begin{array}{c}22.5 \\
4 \\
\end{array}$ & $\begin{array}{c}84.5 \\
2 \\
\end{array}$ & $\begin{array}{c}16.5 \\
8 \\
\end{array}$ & $\begin{array}{c}186 . \\
14 \\
\end{array}$ & $\begin{array}{c}47.0 \\
4 \\
\end{array}$ & $\begin{array}{c}28.9 \\
1 \\
\end{array}$ & 0.56 & 0.06 & -11.4 & -20.1 & $\begin{array}{c}26.0 \\
0 \\
\end{array}$ & 0.10 & $\begin{array}{c}12.6 \\
6 \\
\end{array}$ & $\begin{array}{c}12.7 \\
5 \\
\end{array}$ \\
\hline TTD94 & n.a & 2191 & 6.9 & 30.5 & $\begin{array}{c}47.3 \\
0 \\
\end{array}$ & $\begin{array}{c}61.5 \\
0 \\
\end{array}$ & $\begin{array}{c}323 . \\
00 \\
\end{array}$ & $\begin{array}{c}13.3 \\
0 \\
\end{array}$ & $\begin{array}{c}537 . \\
10 \\
\end{array}$ & $\begin{array}{c}70.8 \\
0 \\
\end{array}$ & $\begin{array}{c}169 . \\
10 \\
\end{array}$ & n.a & n.a & -19.5 & -25.1 & $\begin{array}{c}28.9 \\
0 \\
\end{array}$ & 0.10 & $\begin{array}{c}10.7 \\
0 \\
\end{array}$ & $\begin{array}{c}11.0 \\
9 \\
\end{array}$ \\
\hline $\begin{array}{c}\text { TTD11 } \\
0 \\
\end{array}$ & n.a & 1945 & 6.6 & 30.6 & $\begin{array}{c}47.3 \\
0 \\
\end{array}$ & $\begin{array}{c}56.4 \\
0 \\
\end{array}$ & $\begin{array}{c}281 . \\
20 \\
\end{array}$ & $\begin{array}{c}13.3 \\
0 \\
\end{array}$ & $\begin{array}{c}468 . \\
00 \\
\end{array}$ & $\begin{array}{c}65.3 \\
0 \\
\end{array}$ & $\begin{array}{c}142 . \\
20 \\
\end{array}$ & n.a & $\mathrm{n} . \mathrm{a}$ & -18.1 & -22.6 & $\begin{array}{c}20.9 \\
0 \\
\end{array}$ & 0.10 & $\begin{array}{c}14.3 \\
9 \\
\end{array}$ & $\begin{array}{c}15.1 \\
1 \\
\end{array}$ \\
\hline $\begin{array}{c}\text { ALM7 } \\
3\end{array}$ & n.a & 846 & 6.8 & 30.2 & $\begin{array}{c}44.1 \\
0\end{array}$ & $\begin{array}{c}39.9 \\
0\end{array}$ & $\begin{array}{c}164 . \\
80 \\
\end{array}$ & $\begin{array}{c}21.5 \\
0\end{array}$ & 0.00 & $\begin{array}{c}308 . \\
00\end{array}$ & 2.90 & $\mathrm{n} . \mathrm{a}$ & n.a & -10.1 & -15.4 & $\begin{array}{c}46.2 \\
0 \\
\end{array}$ & 0.30 & 6.89 & 7.25 \\
\hline
\end{tabular}


Table 3

\begin{tabular}{|c|c|c|c|c|c|c|c|c|}
\hline & \multicolumn{2}{|c|}{$\begin{array}{l}\text { Recife (Hydrological } \\
\text { year March 2013- } \\
\text { February 2014) }\end{array}$} & \multicolumn{2}{|c|}{$\begin{array}{c}\text { Belem (1965-1990 } \\
\text { averages) }\end{array}$} & \multicolumn{2}{|c|}{$\begin{array}{c}\text { Manaus (1965-1990 } \\
\text { averages) }\end{array}$} & \multicolumn{2}{|c|}{$\begin{array}{l}\text { Porto Velho (1965- } \\
1983 \text { averages) }\end{array}$} \\
\hline $\begin{array}{l}\text { Sample - } \\
\text { montth-year }\end{array}$ & $\begin{array}{c}\delta^{18} \mathrm{O}(\% 0 \\
\text { vs } \\
\text { VSMOW) } \\
\end{array}$ & $\begin{array}{c}\delta^{2} \mathrm{H}(\% 0 \\
\text { vs } \\
\text { VSMOW }) \\
\end{array}$ & $\begin{array}{c}\delta^{18} \mathrm{O}(\% 0 \\
\text { vs } \\
\text { VSMOW) }\end{array}$ & $\begin{array}{c}\delta^{2} \mathrm{H}(\% 0 \\
\text { vs } \\
\text { VSMOW) } \\
\end{array}$ & $\begin{array}{c}\delta^{18} \mathrm{O}(\% 0 \\
\text { vs } \\
\text { VSMOW) } \\
\end{array}$ & $\begin{array}{c}\delta^{2} \mathrm{H}(\% 0 \\
\text { vs } \\
\text { VSMOW) } \\
\end{array}$ & $\begin{array}{c}\delta^{18} \mathrm{O}(\% 0 \\
\quad \mathrm{vs} \\
\text { VSMOW) } \\
\end{array}$ & \begin{tabular}{|c|}
$\delta^{2} \mathrm{H}(\% 0$ \\
vs \\
VSMOW) \\
\end{tabular} \\
\hline March & $-1,0$ & 3 & $\begin{array}{l}-3.77 \\
\pm 2.31\end{array}$ & $\begin{array}{l}-23.98 \\
\pm 17.09\end{array}$ & $\begin{array}{l}-6.32 \\
\pm 2.16\end{array}$ & $\begin{array}{l}-38.69 \\
\pm 18.23\end{array}$ & $\begin{array}{l}-7.30 \\
\pm 1.51\end{array}$ & $\begin{array}{l}-48.52 \\
\pm 12.67\end{array}$ \\
\hline April & $-2,0$ & -3 & $\begin{array}{l}-5.08 \\
\pm 3.45 \\
\end{array}$ & $\begin{array}{l}-30.10 \\
\pm 27.94 \\
\end{array}$ & $\begin{array}{l}-7.03 \\
\pm 2.61 \\
\end{array}$ & $\begin{array}{l}-43.49 \\
\pm 21.53 \\
\end{array}$ & $\begin{array}{l}-7.70 \\
\pm 3.91 \\
\end{array}$ & $\begin{array}{l}-50.22 \\
\pm 30.44 \\
\end{array}$ \\
\hline May & $-1,5$ & -1 & $\begin{array}{l}-3.17 \\
\pm 2.54\end{array}$ & $\begin{array}{l}-18.56 \\
\pm 18.47\end{array}$ & $\begin{array}{l}-7.18 \\
\pm 3.43\end{array}$ & $\begin{array}{l}-42.52 \\
\pm 30.79\end{array}$ & $\begin{array}{l}-5.25 \\
\pm 3.95\end{array}$ & $\begin{array}{l}-37.84 \\
\pm 28.32\end{array}$ \\
\hline June & $-2,0$ & -4 & $\begin{array}{l}-1.42 \\
\pm 1.52\end{array}$ & $\begin{array}{l}-0.27 \\
\pm 9.54\end{array}$ & $\begin{array}{l}-3.70 \\
\pm 2.18\end{array}$ & $\begin{array}{l}-15.16 \\
\pm 17.65\end{array}$ & $\begin{array}{l}-4.23 \\
\pm 2.78\end{array}$ & $\begin{array}{l}-28.56 \\
\pm 23.11\end{array}$ \\
\hline July & $-1,2$ & 4 & $\begin{array}{l}-1.12 \\
\pm 1.63\end{array}$ & $\begin{array}{l}-2.34 \\
\pm 8.64\end{array}$ & $\begin{array}{l}-2.96 \\
\pm 1.44\end{array}$ & $\begin{array}{c}-8.59 \\
\pm 14.24\end{array}$ & $\begin{array}{l}-2.56 \\
\pm 2.98\end{array}$ & $\begin{array}{l}-15.22 \\
\pm 24.98\end{array}$ \\
\hline August & $-0,9$ & 6 & $\begin{array}{l}-0.39 \\
\pm 1.46 \\
\end{array}$ & $\begin{array}{c}7.50 \\
\pm 7.65 \\
\end{array}$ & $\begin{array}{l}-1.80 \\
\pm 1.63 \\
\end{array}$ & $\begin{array}{c}-4.04 \\
\pm 14.84 \\
\end{array}$ & $\begin{array}{l}-4.39 \\
\pm 2.66 \\
\end{array}$ & $\begin{array}{l}-24.92 \\
\pm 23.55 \\
\end{array}$ \\
\hline September & $-0,5$ & 8 & $\begin{array}{l}-0.22 \\
\pm 1.16 \\
\end{array}$ & $\begin{array}{l}4.95 \\
\pm 9.24 \\
\end{array}$ & $\begin{array}{l}-1.85 \\
\pm 1.40\end{array}$ & $\begin{array}{l}-1.34 \\
\pm 8.78 \\
\end{array}$ & $\begin{array}{l}-1.24 \\
\pm 3.26\end{array}$ & $\begin{array}{c}4.10 \\
\pm 16.18 \\
\end{array}$ \\
\hline October & $-0,8$ & 6 & $\begin{array}{l}-0.28 \\
\pm 1.63\end{array}$ & $\begin{array}{c}3.53 \\
\pm 10.19\end{array}$ & $\begin{array}{l}-1.93 \\
\pm 1.22\end{array}$ & $\begin{array}{l}-3.63 \\
\pm 9.43\end{array}$ & $\begin{array}{l}-3.45 \\
\pm 2.08\end{array}$ & $\begin{array}{l}-17.40 \\
\pm 20.87\end{array}$ \\
\hline November & $-0,7$ & 6 & $\begin{array}{l}-1.02 \\
\pm 1.25\end{array}$ & $\begin{array}{l}-3.75 \\
\pm 11.68\end{array}$ & $\begin{array}{l}-3.54 \\
\pm 1.91\end{array}$ & $\begin{array}{l}-12.81 \\
\pm 10.34\end{array}$ & $\begin{array}{l}-4.92 \\
\pm 3.06\end{array}$ & $\begin{array}{l}-25.54 \\
\pm 22.72\end{array}$ \\
\hline December & $-1,2$ & 1 & $\begin{array}{l}-1.33 \\
\pm 1.93 \\
\end{array}$ & $\begin{array}{c}-4.73 \\
\pm 13.97 \\
\end{array}$ & $\begin{array}{r}-3.30 \\
\pm 1.27 \\
\end{array}$ & $\begin{array}{l}-16.46 \\
\pm 7.97\end{array}$ & $\begin{array}{l}-4.11 \\
\pm 1.16\end{array}$ & $\begin{array}{l}-25.34 \\
\pm 9.19\end{array}$ \\
\hline January & $-1,1$ & 3 & $\begin{array}{l}-2.32 \\
\pm 1.78 \\
\end{array}$ & $\begin{array}{l}-11.02 \\
\pm 11.86\end{array}$ & $\begin{array}{l}-4.14 \\
\pm 1.29\end{array}$ & $\begin{array}{r}-20.50 \\
\pm 10.39\end{array}$ & $\begin{array}{l}-6.49 \\
\pm 3.50\end{array}$ & $\begin{array}{r}-42.73 \\
\pm 30.53\end{array}$ \\
\hline February & $-0,9$ & 5 & $\begin{array}{l}-3.07 \\
\pm 2.08\end{array}$ & $\begin{array}{l}-14.61 \\
\pm 13.89\end{array}$ & $\begin{array}{l}-5.08 \\
\pm 2.20\end{array}$ & $\begin{array}{r}-26.76 \\
\pm 16.26\end{array}$ & $\begin{array}{l}-9.56 \\
\pm 2.86\end{array}$ & $\begin{array}{l}-65.83 \\
\pm 23.94\end{array}$ \\
\hline
\end{tabular}




\section{Table captions}

Table 1: Groundwater data: Stable isotopes of water, d-excess and recharge temperature

Table 2: Geochemical and isotopic data for the dated paleogroundwater and calculated ${ }^{14} \mathrm{C}$ age ranges.

Table 3: Stable isotopes data of precipitations in Recife (Monthly sampling, 2013-2014 period). Comparison with

the average of regional IAEA stations (IAEA/WMO, 2016). The continental effect on isotopic signatures appears to be mostly true all the year long. 
Highlights

$\delta^{18} \mathrm{O}, \delta^{2} \mathrm{H}$ and d-excess are analyzed in NE Brazil modern and Mid Holocene groundwater They are compared to speleothem $\delta^{18} \mathrm{O}$ rainfall amount proxy, available for this period d-excess shows that rainfall increase was accompanied with moisture recycling Recycling argues for rain forest settlement during Early-Mid Holocene d-excess seems then to be a promising tool for paleoecological studies of the area. 